DZIEJE NAJNOWSZE, ROCZNIK XLVIII — 2016, 1

PL ISSN 0419-8824

\title{
Daniel Wicenty
}

Gdańsk

\section{Kiszczakowska „policja w policji”. O Zarządzie Ochrony Funkcjonariuszy (1985-1990)}

12 XII 1984 r. gen. Czesław Kiszczak, ówczesny szef MSW, poinformował gen. Wojciecha Jaruzelskiego, ówczesnego premiera, o powołaniu pionu, „który zajmowałby się zagadnieniami ochrony funkcjonariuszy i pracowników cywilnych w resorcie"1. W istocie chodziło o Zarząd Ochrony Funkcjonariuszy, komórkę formalnie powołaną do życia przez gen. Kiszczaka 27 grudnia tegoż roku i pełniącą klasyczną funkcję „wewnętrznej policji” dla całego resortu spraw wewnętrznych.

Zarząd Ochrony Funkcjonariuszy jest jak dotąd strukturą słabo opisaną ${ }^{2}$. Podstawowym celem niniejszego tekstu będzie więc zaprezentowanie okoliczności powstania ZOF oraz syn-

\footnotetext{
${ }^{1}$ AIPN, 55/18, Pismo nr OP-I-003389/84 ministra spraw wewnętrznych do prezesa rady ministrów, 12 XII 1984, k. 7.

${ }^{2}$ Wzmianki o ZOF (podstawowe informacje o strukturze i zadaniach) zawarte są tekstach Pawła Piotrowskiego (idem, Stużba Bezpieczeństwa w latach 1975-1990, w: Aparat bezpieczeństwa w Polsce. Kadra kierownicza, t. III: 1975-1990, red. idem, Warszawa 2008, s. 14, 31-32, 49; idem, Przemiany w MSW w latach 1989-1990, „Biuletyn IPN” 2004, nr 4, s. 47). Równie lakoniczny jest Henryk Dominiczak, który w swojej monografii aparatu bezpieczeństwa poświęca ZOF jeden krótki akapit, pisząc tam o wzorowaniu się na rozwiązaniach z MBP (idem, Organy bezpieczeństwa PRL 1944-1990. Rozwój i działalność w świetle dokumentów MSW, Warszawa 1997, s. 252). Wstępny, porządkujący i formalny opis ZOF oferuje tekst Anny Marcinkiewicz-Kaczmarczyk (eadem, Zarzad Ochrony Funkcjonariuszy w walce z korupcja w latach 1984-1990, w: Społeczno-prawne aspekty przeciwdziałania korupcji, red. J. Bil, A. Wawrzusiszyn, Szczytno 2012). Z kolei Piotr Milczanowski w komentarzu do opracowanych dokumentów (w tym sprawozdań krakowskiego i nowosądeckiego Inspektoratu Ochrony Funkcjonariuszy) kilka akapitów poświęcił Zarządowi, opisując jego podstawowe funkcje zob. Morale funkcjonariuszy SB i MO w Matopolsce w ostatnich latach PRL (wybór dokumentów), oprac. P. Milczanowski, „Zeszyty Historyczne WiN-u” 2010, nr 32-33. Poza tym o ZOF w formie popularnonaukowej pisał autor niniejszego tekstu na łamach miesięcznika „Debata” (D. Wicenty, Patologie peerelowskiego MSW. Wypiski z akt Zarządu Ochrony Funkcjonariuszy. Część 1: Alkoholizm, „Debata: miesięcznik regionalny” 2013, nr 8; idem, Patologie peerelowskiego MSW. Wypiski z akt Zarządu Ochrony Funkcjonariuszy. Część 2: Zbójecka przedsiębiorczość, ibidem, nr 9; idem, Patologie peerelowskiego MSW. Wypiski z akt Zarzadu Ochrony Funkcjonariuszy. Część 3: Paszporty, ibidem, nr 10; idem, Patologie peerelowskiego MSW. Wypiski z akt Zarządu Ochrony Funkcjonariuszy. Część 4:
} 
tetycznego obrazu jego funkcjonowania przez pryzmat zadań, uprawnień, struktury i kadr. Spróbujemy także naszkicować obszar pól badawczych, jakie otwierają się przed naukowcami zajmującymi się aparatem bezpieki w jej schyłkowym okresie dzięki analizie dokumentów ZOF.

\section{Okoliczności i cele powstania ZOF}

W kilkudziesięcioletniej historii peerelowskiego aparatu bezpieczeństwa jedynie przez pewien czas funkcjonowała komórka podobna do ZOF. W latach 1945-1955 był to Wydział (Biuro) ds. Funkcjonariuszy powołany przez ministra Stanisława Radkiewicza. Krzysztof Szwagrzyk, opisując powstanie wydziału, zwrócił uwagę m.in. na napływ do aparatu bezpieczeństwa ludzi przypadkowych lub/i zdemoralizowanych wynikający z nowego kanału awansu oraz słabego procesu selekcji kandydatów ${ }^{3}$. Wydział miał szerokie uprawnienia: przeprowadzał czynności dochodzeniowe i śledcze, dokonywał aresztowań i rewizji, zabezpieczał dowody, przeprowadzał przesłuchania, a nawet prowadził „sieć informacyjną w Milicji Obywatelskiej”"4. Henryk Dominiczak pisał o Wydziale ds. Funkcjonariuszy jako odpowiedniku Głównego Zarządu Informacji ${ }^{5}$, stąd pamięć resortowa o tej komórce nie była najlepsza. Gen. Kiszczak, prezentując pomysł stworzenia ZOF kierownictwu MSW, stwierdził: „Towarzysze, pamiętać musimy, jak zapisały się w pamięci resortu spraw wewnętrznych doświadczenia z działalności pionu do spraw funkcjonariuszy przy tworzeniu naszego aparatu. Wypaczenia w jego działalności, a zwłaszcza nadużycia szerokich uprawnień w zakresie ujawniania i likwidowania przypadków naruszeń prawa i dyscypliny, doprowadziły do jego likwidacji w 1955 r.”6 Przesłanki dla stworzenia ZOF były jednak według gen. Kiszczaka poważniejsze: „Pamiętać musimy, że przeciwnik polityczny [...] wykorzystywał, wykorzystuje i będzie wykorzystywał każde nasze potknięcie, każdy przypadek naruszenia prawa przez funkcjonariuszy resortu spraw wewnętrznych. Sprawy takie przytrafiają się zdecydowanie za często, a ich charakter budzi coraz większy niepokój. Śledztwo dot. zabójstwa Jerzego Popiełuszki, sprawy z Gdańska czy z Wrocławia, w toku których ujawnione zostały próby infiltracji naszego aparatu przez przeciwnika politycznego, postępowania karne przeciwko funkcjonariuszom o łapówki i płatną protekcję, przypadki nadmiernego bogacenia się z niewiadomych lub podejrzanych źródeł — to sprawy uzasadniające konieczność zajęcia

Socjalistyczna moralność w aparacie bezpieczeństwa, ibidem, nr 11; idem, Patologie peerelowskiego MSW. Wypiski z akt Zarząu Ochrony Funkcjonariuszy. Część 5: (De)konspiracje, ibidem 2014, nr 1; wszystkie teksty dostępne na stronie http://www.debata.olsztyn.pl). Ponadto na konferencji naukowej „Przestępczość funkcjonariuszy MBP i MSW” (IPN, Szczecin, 21-22 V 2014 r.) pojawiły się trzy referaty poświęcone funkcjonowaniu ZOF (w tym wystąpienie Typy i skala przewinień funkcjonariuszy SB w perspektywie Zarzadu Ochrony Funkcjonariuszy MSW. Wstepne ustalenia, hipotezy i postulaty autora niniejszego tekstu).

${ }^{3}$ K. Szwagrzyk, Aparat bezpieczeństwa w latach 1944-1956, w: Aparat bezpieczeństwa w Polsce. Kadra kierownicza, t. I: 1944-1956, red. idem, Warszawa 2005, s. 67.

${ }^{4}$ AIPN, 55/18, Rozkaz nr 30 o organizacji Biura do Spraw Funkcjonariuszy Bezpieczeństwa Publicznego, 23 VI 1949 r., k. 3.

${ }^{5}$ H. Dominiczak, Organy bezpieczeństwa, s. 25.

${ }^{6}$ AIPN, 55/18 [Referat ministra spraw wewnętrznych], b.d., k. 25. Wątek „wypaczeń” z lat czterdziestych i pięćdziesiątych pojawił się także na naradzie z funkcjonariuszami wojewódzkich Inspektoratów Ochrony Funkcjonariuszy z końca maja 1985 r. (AIPN Po, 078/2, t. 3, Notatka służbowa z narady w Zarządzie Ochrony Funkcjonariuszy Warszawa 29-30 V 1985, 3 VI 1985, k. 183). 
zdecydowanego stanowiska i podjęcia stosownych decyzji’’ ${ }^{\prime \prime}$ Z grubsza rzecz biorąc, chodzić miało przede wszystkim o rozprzężenie dyscyplinarne funkcjonariuszy. Abstrahując od innych wskazanych przez Kiszczaka wątków, przyjrzyjmy się najpierw stanowi dyscypliny w MSW w roku 1984 w odniesieniu do lat wcześniejszych. Dane o przewinieniach funkcjonariuszy (była to kategoria szeroka ${ }^{8}$ ) zbierał systematycznie Główny Inspektorat Ministra Spraw Wewnętrznych.

Tabela nr 1

\begin{tabular}{|c|c|c|c|c|c|c|}
\hline Rok & $\mathbf{1 9 8 0}$ & $\mathbf{1 9 8 1}$ & $\mathbf{1 9 8 2}$ & $\mathbf{1 9 8 3}$ & $\mathbf{1 9 8 4}$ & $\mathbf{1 9 8 5}$ \\
\hline Liczba przewinień & 6733 & 4892 & 7466 & 7982 & 7217 & 7152 \\
\hline
\end{tabular}

Źródło: opracowanie własne na podstawie AIPN, 1091/233.

Skokowy wzrost przewinień dotyczył lat stanu wojennego, zwłaszcza 1981-1982 (wzrost o ponad 50 proc.). Nawiasem mówiąc, sprawozdania resortowe sugerują pewną bezradność poznawczą wobec tego fenomenu. Przykładowo, w sprawozdaniu GIM za rok 1982 czytamy, że przyczyną obniżenia dyscypliny miały być „,napięcia w społeczeństwie”, „naciski na psychikę funkcjonariuszy”, powodujące ,znaczną nerwowość w czasie pełnienia służby, a nawet po służbie”, oraz ,prowokacje ze strony ekstremy «Solidarności» oraz inne działania zmierzające do kompromitacji i osłabiania kondycji psychicznej funkcjonariuszy". Z kolei w sprawozdaniu WUSW w Opolu za rok 1983 zauważony tam przyrost liczby przewinień tłumaczono... zniesieniem stanu wojennego ${ }^{10}$. Trudno uniknąć wrażenia, że z jednej strony analitycy resortu ulegli własnej propagandzie (,ekstrema «Solidarności»”), z drugiej zaś temu samemu czynnikowi przypisywali zgoła odmienne skutki oddziaływań na dyscyplinę funkcjonariuszy. W każdym razie statystyczny stan dyscypliny w MSW w pierwszej połowie lat osiemdziesiątych najgorzej prezentował się latach 1982-1983, a w roku 1984 już się trochę poprawił. Gdyby więc ta przesłanka miała być przesądzająca, gen. Kiszczak powinien utworzyć ZOF rok wcześniej.

Zastanówmy się jeszcze nad dwoma pozostałymi powodami wskazanymi przez Kiszczaka. W referacie poruszył wątek morderstwa ks. Jerzego Popiełuszki, w domyśle świadczący o skrajnym rozprzężeniu i samowoli w resorcie. Abstrahując od współczesnych dyskusji dotyczących okoliczności zbrodni, tezę o samowoli funkcjonariuszy należy uznać za gruntownie fałszywą. Od kilku lat znane już są dokumenty ze spraw „Teresa”, „Robot” i „Trawa”. Wskazują one, że oficjalna wersja zdarzeń wynikająca z procesu toruńskiego została spreparowana przez gen. Kiszczaka i jego współpracowników z MSW. Dokumenty z trwa-

\footnotetext{
${ }^{7}$ AIPN, 55/18 [Referat ministra spraw wewnętrznych], b.d., k. 24.

${ }^{8}$ Przewinienia obejmowały kontakty z ,elementem przestępczym” i z obcymi służbami specjalnymi, podejrzane kontakty z cudzoziemcami, przestępstwa kryminalne i gospodarcze, naruszenia tajemnicy państwowej i służbowej, nieuzasadnione wzbogacenie się oraz przewinienia dyscyplinarne. W ramach tej ostatniej kategorii zwracano uwagę m.in. na gubienie dokumentów, prowadzenie pojazdu w stanie nietrzeźwym, spożywanie alkoholu na służbie oraz odmowę wykonania polecenia służbowego. Oprócz tego analizowano tzw. wydarzenia nadzwyczajne, które obejmowały samobójstwa funkcjonariuszy, wypadki z bronią (np. przypadkowe postrzały, zaginięcia broni), pobicia obywateli i inne nieszczęśliwe wypadki (na podstawie: AIPN, 0789/1, t. 1; AIPN Gd, 0046/80, t. 2).

9 AIPN, 1091/233, Informacja o przestępstwach i przewinieniach służbowych popełnionych przez funkcjonariuszy MO i SB w 1982 roku, 30 III 1983, k. 25.

${ }^{10}$ AIPN, 1585/9296, Sprawozdanie o stanie dyscypliny funkcjonariuszy województwa opolskiego za 1983 r., 23 I 1984, k. 22.
} 
jącej ponad pięć lat inwigilacji rodzin i bliskich czterech funkcjonariuszy Departamentu IV skazanych w procesie oraz uruchomienie mechanizmów kozła ofiarnego doskonale to pokazują. Ujawniają także zestaw narzędzi kontroli nad resortem, którymi gen. Kiszczak dysponował ${ }^{11}$. W tym kontekście teza o samowoli w MSW wygląda co najmniej niepoważnie. Wreszcie spójrzmy na związek między powołaniem ZOF a morderstwem ks. Popiełuszki od czysto biurokratycznej strony. Oficjalnie ciało księdza odnaleziono 30 X 1984 r., Zarząd zaś zaczął funkcjonować 1 I 1985 r. Czy dwa miesiące dzielące te wydarzenia można uznać za wystarczające dla podjęcia wysiłku koncepcyjnego, planistycznego i administracyjnego, koniecznego dla stworzenia całkowicie nowej struktury w MSW o unikatowych uprawnieniach i zadaniach? Z pewnością nie. Morderstwo kapelana Solidarności można ocenić jako pozorną przesłankę powołania ZOF.

Kiszczak mówił też enigmatycznie o „sprawach z Gdańska i Wrocławia”. Chodzi tu o przypadki kpt. Adama Hodysza oraz kpt. Mariana Charukiewicza, funkcjonariuszy współpracujących z opozycją ${ }^{12}$. Kpt. Hodysz od 1978 r. przekazywał informacje gdańskiemu środowisku Ruchu Młodej Polski, potem zaś Solidarności. Gdańska SB prawdopodobnie od 1980 r. świadoma była, że w jej szeregach pracuje „kret”. Niemniej jednak kpt. Hodysz został zatrzymany dopiero w październiku 1984 r., a we wrześniu 1985 r. skazany na trzy lata więzienia $^{13}$. Kpt. Charukiewicz podjął współpracę z wrocławskimi środowiskami opozycyj-

${ }^{11}$ Na razie można tu odesłać jedynie do popularnonaukowej książki Wojciecha Sumlińskiego Teresa, Trawa, Robot. Największa operacja komunistycznych stużb specjalnych, Warszawa 2009. Zob. także L. Pietrzak, Nieznana prawda o śmierci ks. Jerzego Popietuszki, „Polska the Times”, 28 X 2008 r. (dostęp na: http://www.polskatimes.pl/artykul/53946,nieznana-prawda-o-smierci-ks-jerzego-popieluszki,id,t. html? cookie=1, ostatnia wizyta 26 VII 2013). Nawiasem mówiąc, sprawę „Teresa” (kontrola operacyjna matki żony płk. Adama Pietruszki, skazanego w procesie zabójców ks. Popiełuszki) prowadził właśnie ZOF (konkretnie: wrocławski IOF; AIPN, 0859/735, k. 313-401). Niezależnie od tego od początku 1985 r. ZOF prowadził także SOR „Brutus”, której przedmiotem była zagubiona broń i wyciek kilku dokumentów z lat 1981-1982 w Departamencie IV (AIPN, 0789/27). A dodatkowo od 8 do 27 XI 1984 r. w Departamencie IV trwała doraźna kontrola prowadzona przez Główny Inspektorat Ministra (AIPN, 0859/154). W przypadku obu tych postępowań można odnieść wrażenie, że kierownictwo MSW szukało „haków”. Ustalenia ZOF i GIM nie były jednak druzgocące (spory personalne, nadużycia związane z funduszem „O”). Dały jednak solidny pretekst do sformułowania tezy o fatalnej sytuacji polityczno-kadrowej w Departamencie IV — w domyśle także tezy o samowoli wiążącej się z morderstwem ks. Popiełuszki.

${ }_{12}$ Zob. S. Cenckiewicz, Operacja „Arka”, czyli SB w walce z Ruchem Młodej Polski, w: idem, Oczami bezpieki. Szkice i materiały z dziejów aparatu bezpieczeństwa PRL, Kraków 2006, wyd. 3, s. 399-401; P. Gontarczyk, S. Cenckiewicz, SB a Lech Watęsa. Przyczynek do biografii, Gdańsk-WarszawaKraków 2008, s. 151, 152; J. Kordas, Piłsudczycy w Komendzie Wojewódzkiej Milicji Obywatelskiej we Wrocławiu — „Grupa Charukiewicza”, w: Czas przełomu: Solidarność 1980-1981, red. W. Polak i in., Gdańsk 2010, s. 629-657.

${ }^{13}$ Sąd Najwyższy podwyższył wyrok dla kpt. Hodysza do sześciu lat. Wyszedł na wolność 30 XII 1988 r. W sierpniu 1990 r. został uniewinniony. W latach 1990-2001 pracował w UOP (gdzie dosłużył się stopnia podpułkownika). Razem z kpt. Hodyszem sądzony był inny funkcjonariusz gdańskiego Wydziału Śledczego, szer. Piotr Siedliński, któremu Hodysz zaproponował współpracę w 1982 r. Siedlińskiego skazano początkowo na półtora roku więzienia, po czym Sąd Najwyższy podwyższył tę karę do czterech lat. Siedliński do więzienia nie trafił (ukrywał się) i podobnie jak Hodysz został uniewinniony w sierpniu 1990 r. (szczegóły procesu Hodysza i Siedlińskiego opisuje na swojej stronie adwokat Edward Stępień, Sprawa Hodysza i Siedlińskiego, http://www.edwardstepien.pl/artykuly/ artykuly-naukowe/05-sprawa-hodysza-i-siedlinskiego/\#_ftnref35, ostatnia wizyta 4 VI 2014). 
nymi w 1977 r., potem m.in. z Solidarnością Walczącą. Pomimo toczącego się przeciwko niemu postępowania dyscyplinarnego i podejrzeń o ,zdradę" uniknął procesu i więzienia, ale w lipcu 1982 r. został zwolniony z MSW. Przypadek Charukiewicza jest o tyle specyficzny, że — jak się zdaje — był on nieformalnym przywódcą szerszej grupy ,zdrajców” z MSW przekazujących informacje opozycji. Gen. Kiszczak miał więc rację o tyle, że dochodziło do przypadków ,infiltracji aparatu przez przeciwnika politycznego”. Były one jednak odosobnione, a stopień ich destruktywności dla resortu wymaga odrębnej analizy.

Pozostaje jednak pytanie o rzeczywiste powody powołania ZOF. Hipotetyczna odpowiedź brzmiałaby mniej więcej tak: w drugiej połowie 1984 r. mieliśmy do czynienia z całą serią zdarzeń kształtujących układ sił w i wokół MSW. W lipcu tego roku specjalna komisja ukończyła raport poświęcony aferze „Żelazo”, wskazując jako głównego winowajcę gen. Mirosława Milewskiego ${ }^{14}$, poprzedniego ministra spraw wewnętrznych, ówczesnego członka Biura Politycznego, a zarazem konkurenta gen. Kiszczaka do nadzoru nad resortem. W październiku zamordowano ks. Popiełuszkę. Andrzej Paczkowski pisze, że pod koniec 1984 r. najbliższe otoczenie gen. Jaruzelskiego uważało, że za morderstwem ks. Jerzego mógł stać właśnie gen. Milewski ${ }^{15}$. Zarzut roli mocodawcy morderców ks. Jerzego można jednak uznać za sztucznie imputowany. Gen. Milewski definitywnie wypadł ze struktur władzy w 1985 r. ze względu na aferę „Żelazo”. Może była to jedna z opcji — nieudanych — „konstruowania odpowiedzialności za zbrodnię”, jak to określił Leszek Pietrzak ${ }^{16}$.

Z kolei morderstwo ks. Jerzego stało się elementem kolejnego wymiaru gry Kiszczaka wobec opinii publicznej, kierownictwa partii i funkcjonariuszy MSW. Chodziło o publiczną inscenizację, która miała odsunąć odium związane z morderstwem od $\mathrm{MSW}^{17}$. Zasadniczą częścią tej gry byłoby upowszechnienie tezy o „czarnych owcach”, które samowolnie dopuściły się zbrodni. 29 października (czy wyprzedzająco wobec oficjalnego momentu odnalezienia ciała księdza?) ,Trybuna Ludu” przedrukowała wystąpienie radiowo-telewizyjne gen. Kiszczaka, w którym znalazł się m.in. następujący fragment: „Byłoby naiwnością oczekiwać, że akurat w resorcie spraw wewnętrznych nie znajdą się w ogóle osobnicy podatni na demoralizację. W pełni zdajemy sobie z tego sprawę i wyciągamy stosowne wnioski. Kilkakrotnie informowałem Sejm Polskiej Rzeczypospolitej Ludowej i społeczeństwo o procesie ciągłego samooczyszczania się naszego resortu. [...] Jest to proces naturalny i będziemy go kontynuować"18. 7 listopada „Trybuna” przedrukowała kolejne wystąpienie Kiszczaka, tym razem z posiedzenia sejmowej Komisji Spraw Wewnętrznych i Wymiaru Sprawiedliwości: „Ci, którzy dopuścili się czynów przestępczych i wykroczeń, czynów godzących w dobre imię funkcjonariuszy, muszą odejść i odchodzą z resortu. [...] Jesteśmy jednak świadomi, że nawet pojedynczy i odosobniony przypadek naruszania prawa może wywoływać i wywołuje poważne reperkusje społeczne i polityczne, wykraczające niekiedy poza granice naszego kraju.

\footnotetext{
${ }^{14}$ P. Gontarczyk, Raport z działalności Komisji powołanej do wyjaśnienia charakteru operacji kryptonim „ŻELAZO”, „Glaukopis” 2006, nr 7/8, s. 233-271; Afera „Żelazo” w dokumentach MSW i PZPR, wybór, wstęp i oprac. W. Bagieński, P. Gontarczyk, Warszawa 2013.

${ }^{15}$ A. Paczkowski, PZPR a aparat bezpieczeństwa. Zarys problemu, w: PZPR jako machina władzy, red. D. Stola, K. Persak, Warszawa 2012, s. 196. Informacja ta pochodzi z notatki płk. Wiesława Górnickiego, doradcy gen. Jaruzelskiego, z narady z 25 X 1984 r. w gabinecie Jaruzelskiego (brał w niej udział sam Górnicki).

${ }^{16}$ L. Pietrzak, Nieznana prawda o śmierci.

17 Zob. J. Kurczewski, Teatr Kiszczaka, „Wprost” 2005, nr 43.

${ }^{18}$ Wystapienie radiowo-telewizyjne Cz. Kiszczaka z 27 X 1984 r., „Trybuna Ludu”, 29 X 1984, s. 2.
} 
Sprawa księdza Jerzego Popiełuszki, która zbulwersowała społeczeństwo, w tym funkcjonariuszy — jest tego dobitnym przykładem"19.

Przy tych próbach sterowania opinią publiczną przemycono niejako jeszcze jeden wątek „czarnych owiec”: Hodysza i Siedlińskiego. O ich aresztowaniu (odpowiednio: 24 i 23 października) poinformowały od razu reżimowa telewizja i prasa. Działo się to na kilka dni przed odnalezieniem ciała kapelana Solidarności. 25 października „Trybuna Ludu” zamieściła notkę PAP informującą o ,,aresztowaniu funkcjonariusza WUSW w Gdańsku Piotra S." ${ }^{20}$ Obok tej notki na tej samej stronie pojawiła się inna informacja PAP — o śledztwie w sprawie uprowadzenia ks. Popiełuszki. Dzień później „Trybuna” przedrukowała materiał PAP o aresztowaniu Hodysza $^{21}$, publikując - ponownie obok niego — komunikaty MSW o tymczasowym aresztowaniu funkcjonariuszy MSW podejrzewanych o uprowadzenie ks. Jerzego. Notki $\mathrm{z}$ „Trybuny Ludu” poświęcone gdańskim funkcjonariuszom można uznać za nieprzypadkowe, tak jak i ich zamieszczenie obok informacji na temat uprowadzenia ks. Jerzego. Czy obok procesu toruńskiego — przypadki Hodysza i Siedlińskiego miały stanowić ilustrację „samooczyszczania się resortu”? Jeśli tak, to zamysł ten został potem porzucony. „Trybuna Ludu" o dalszych losach Hodysza i Siedlińskiego milczała. Niejasny jest także powód, dla którego jesienią 1984 r. w więzieniu na Mokotowie Hodysza osadzono razem z płk. Adamem Pietruszką, a Siedlińskiego z por. Waldemarem Chmielewskim ${ }^{22}$.

Możemy jednak zaryzykować hipotezę, że nie miało to charakteru czystej koincydencji. Kontekstem łączącym wszystkie te wydarzenia mogło być właśnie powołanie ZOF, który miał się stać jeszcze jednym narzędziem kontroli gen. Kiszczaka nad MSW. Kiszczak był bowiem nie tylko pomysłodawcą ZOF — w ramach podziału zakresu uprawnień w kierownictwie ministerstwa sprawował nad nim także bezpośrednią kontrolę. Przy tym należy pamiętać, że stanowił on w gruncie rzeczy „ciało obce” w aparacie SB. Aż do 1981 r. całe zawodowe życie związany był z wojskiem. Zarazem status prawej ręki gen. Jaruzelskiego dawał mu znaczną swobodę w kierowaniu MSW. Co więcej, jak wskazuje Sławomir Cenckiewicz, „rola Kiszczaka wykraczała zresztą poza formalnie pełnioną funkcję ministra spraw wewnętrznych. W rzeczywistości nadzorował nie tylko cywilną bezpiekę, ale także wywiad i kontrwywiad wojskowy, którymi kierowali ludzie związani z nim od lat"23. W tym kontekście trzeba zaakcentować kwestię zawłaszczania struktur cywilnej bezpieki przez wojskowych, zapoczątkowanego tuż po nominacji Kiszczaka na szefa MSW w lipcu $1981 \mathrm{r}$. Proces ten miał co najmniej kilka wymiarów ${ }^{24}$. Po pierwsze, chodziło o nowe struktury organizacyjne wewnątrz resortu, pozwalające kontrolować i dyscyplinować funkcjonariuszy (już w listo-

\footnotetext{
${ }^{19}$ Posiedzenie Sejmowej Komisji Spraw Wewnętrznych i Wymiaru Sprawiedliwości. Informacja ministra Cz. Kiszczaka, ibidem, 7 XI 1984, s. 2.

${ }^{20}$ PAP, Aresztowanie funkcjonariusza WUSW $w$ Gdańsku podejrzanego o wspótpracę z nielegalnymi strukturami konspiracyjnymi, ibidem, 25 X 1984, s. 5.

${ }^{21}$ Ibidem, Aresztowanie funkcjonariusza WUSW w Gdańsku - Adama H., ibidem, 26 X 1984, s. 5.

${ }_{22}$ M. Szporer, Solidarity. The Great Workers Strike of 1980, Lanham 2012, s. 69 (rozdz. VII: The Morality of Truth. Conversation with Adam Hodysz).

${ }^{23}$ S. Cenckiewicz, Dlugie ramię Moskwy. Wywiad wojskowy Polski Ludowej 1943-1991 (wprowadzenie do syntezy), Poznań 2011, s. 261, 262.

${ }^{24}$ Militaryzacja struktur SB przez Kiszczaka nie stała się dotąd przedmiotem szczegółowych analiz i funkcjonuje w dyskursie historiograficznym jako teza samooczywista (zob. np. A. Paczkowski, PZPR a aparat bezpieczeństwa. Zarys problemu, w: PZPR jako machina władzy, red. D. Stola, K. Persak, Warszawa 2012, s. 193). Proces ten był elementem szerszego zjawiska - militaryzacji struktur państwa wiążącej się z objęciem przez gen. Jaruzelskiego funkcji I sekretarza KC PZPR, a następnie wprowadzeniem stanu wojennego (częściowej analizy tego problemu dokonuje Andrzej Paczkowski -
} 
padzie 1981 r. powstał pion polityczno-wychowawczy). Po drugie, proces przejmowania MSW przez wojskowych oznaczał obejmowanie stanowisk kierowniczych przez protegowanych gen. Kiszczaka, wywodzących się m.in. z WSW oraz Zarządu II Sztabu Generalnego LWP. Wymienia ich Paweł Piotrowski: „Wśród nich byli: gen. Lucjan Czubiński, od listopada 1981 r. dyrektor generalny w MSW, a od 1983 r. wiceminister; płk Henryk Dankowski, szef Zarządu WSW Pomorskiego Okręgu Wojskowego, w MSW od maja 1982 r., kolejno pełnił funkcje dyrektora Departamentu III MSW, podsekretarza stanu, szefa SB MSW oraz I zastępcy ministra; gen. bryg. Władysław Jura, od końca 1983 r. dyrektor generalny w MSW i szef Służby Polityczno-Wychowawczej; płk Stanisław Stępień, w resorcie od 1984 r., później zastępca dyrektora Biura Studiów SB MSW i Departamentu Studiów i Analiz; płk Ryszard Iwanciów, oficer Zarządu II SG WP, od 1987 r. doradca ministra; płk Ludwik Mochejski, również oficer Zarządu II SG WP i od 1983 r. doradca ministra; płk Czesław Żmuda, od listopada 1981 r. zastępca dyrektora Gabinetu Ministra, a następnie jego dyrektor"25. Listę tę uzupełniają płk Romuald Zajkowski (w WSW w latach 1958-1983), mianowany przez Kiszczaka naczelnikiem Wydziału II w $\mathrm{GIM}^{26}$, oraz wieloletni wopista gen. Edward Tarała, pierwszy szef pionu polityczno-wychowawczego (do listopada 1987 r.). Po trzecie, mieliśmy do czynienia z wprowadzaniem oficerów wojska na niższe stanowiska, zarówno w centrali, jak i strukturach wojewódzkich. Przykładowo, do wrocławskiej bezpieki wojskowi mieli trafiać w dwóch falach: po kryzysie bydgoskim w 1981 r., a następnie po wprowadzeniu stanu wojennego ${ }^{27}$.

W kontekście ZOF zbiegają się tu wszystkie trzy aspekty. Zarząd jako całkowicie nowa struktura był autorskim pomysłem Kiszczaka. Co więcej, można się tu zasadnie dopatrywać wzorców wojskowych - i w kwestii organizacji, i w filozofii działania (podobnie zresztą było w przypadku pionu polityczno-wychowawczego) ${ }^{28}$. Funkcję wicedyrektora (od grudnia 1984 r. do listopada 1987 r.), a następnie krótko dyrektora ZOF (do listopada do grudnia 1987 r.) objął płk Stanisław Dębski, wieloletni oficer WSW. Co najmniej jako hipotezę trzeba tu przywołać kwestię obsadzenia stanowisk w ZOF przez innych funkcjonariuszy wcześniej związanych z wojskiem ${ }^{29}$.

\section{Struktura i kadry}

ZOF podlegał bezpośrednio ministrowi spraw wewnętrznych. Oprócz kierownictwa w jego ramach funkcjonowały cztery zespoły, których zakres działania wyglądał następująco:

- Zespół I ds. SB (departamenty I-VI, Biuro Studiów, Biuro Śledcze, Główny Inspektorat Ministra, BOR, biura: „A”, „B”, „C”, „T” i „W”, Departament Techniki,

\footnotetext{
idem, Dowódca czy przywódca? Wojciech Jaruzelski 1981-1989, w: Władza w PRL. Ludzie i mechanizmy, red. K. Rokicki, R. Spałek, Warszawa 2011, s. 267, 268, 272, 273).

${ }_{25}$ P. Piotrowski, Stużba Bezpieczeństwa w latach, s. 13, 14.

${ }^{26}$ S. Cenckiewicz, Dtugie ramie Moskwy, s. 261, 262.

${ }^{27}$ J. Kordas, Pitsudczycy w Komendzie Wojewódzkiej, s. 646, 648, 649. Zresztą problem obecności oficerów LWP w cywilnej bezpiece po $1981 \mathrm{r}$. jest badawczo zaledwie rozpoznany.

${ }^{28}$ Por. S. Cenckiewicz, Dlugie ramię Moskwy, s. 265; A. Marcinkiewicz-Kaczmarczyk, Wojskowa Stużba Wewnętrzna. Organizacja i zakres zadań, w: Archiwalia komunistycznego aparatu represji zagadnienia źródloznawcze, red. F. Musiał, Kraków 2012, s. 199-275.

${ }_{29}$ Z pewnością jest to przypadek ppłk. Wojciecha Busslera (w latach 1963-1987 oficera WSW), który znalazł się w centrali ZOF w 1988 r. (AIPN, 2555/1468; AIPN, 0604/1856, t. 1-2).
} 
Zarząd I, Biuro Paszportów, Gabinet Ministra, Zarząd Polityczno-Wychowawczy i Biuro RKW);

— Zespół II ds. MO (biura: Operacyjne, Ruchu Drogowego, Prewencji, Kryminalne, do Walki z Przestępstwami Gospodarczymi, Dochodzeniowo-Śledcze, Kontroli i Analiz, Zakład Kryminalistyki);

— Zespół III ds. Pracowników Cywilnych (Biuro Organizacyjno-Prawne, departamenty: PESEL, Kadr, Szkolenia i Doskonalenia Zawodowego, Społeczno-Administracyjny, Finansów, Zdrowia i Spraw Socjalnych, Inwestycji, Gospodarki Materiałowo-Technicznej, zarządy: Łączności, Administracyjno-Gospodarczy, Główny Inspektorat Ochrony Przemysłu, redakcja „W służbie narodu”);

— Zespół IV ds. Analitycznych i Ogólnych ${ }^{30}$.

Zespół I zatrudniał sześciu pracowników, II — ośmiu, III — czterech, a IV — siedmiu (w tym sekretarkę i dwóch kierowców) $)^{31}$.

Struktura ta nie determinowała rozwiązań organizacyjnych w wojewódzkich inspektoratach (podlegających bezpośrednio szefom WUSW) — przede wszystkim ze względu na różną liczbę funkcjonariuszy zatrudnianych w konkretnych IOF (o czym dalej). Przykładowo, w gdańskim IOF podział pracy wyglądał następująco:

— ppłk Kazimierz Koźmiański (kierownik w latach 1985-1987) oprócz nadzoru merytorycznego miał też pieczę nad sprawami organizacyjnymi i kadrowymi wewnątrz Inspektoratu;

— kpt. Edmund Mucha odpowiadał za wydziały: do Walki z Przestępstwami Gospodarczymi, Kadr, Polityczno-Wychowawczy, Specjalny, Gospodarki Materiałowo-Technicznej, Transportu, Wojewódzkie Stanowisko Kierowania, Zarząd Zdrowia i Spraw Socjalnych oraz MUSW w Gdańsku i Sopocie;

- mjr Janusz Gałdyn odpowiadał za wydziały: Śledczy, Dochodzeniowo-Śledczy, Ruchu Drogowego, Inspekcji, Łączności, RUSW w Gdyni, Starogardzie Gdańskim i Tczewie oraz ośrodki wczasowe w Juracie, Sopocie, Jastarni i Jastrzębiej Górze;

- mjr. Czesławowi Piotrowskiemu podlegały sprawy związane z ZOMO;

— por. Krzysztof Urban odpowiadał za wydziały: II, III, III-1, IV, V, VI, „B”, „C”, „T”, „W”, Paszportów, Samodzielną Sekcję „A”, Inspektorat I i II, Inspektorat Ochrony Przemysłu oraz radiokontrwywiad;

— kpt. Zbigniew Senger miał nadzór na wydziałami: Kryminalnym, Prewencji, Kryminalistyki, Ogólnym, Szkolenia, Finansowym, Inwestycji i Remontów, a także Grupą „S” oraz RUSW w Wejherowie, Kartuzach, Kościerzynie, Pruszczu Gdańskim i Pucku;

- plut. Violetta Konkol na etacie sekretarki-maszynistki odpowiadała za funkcjonowanie sekretariatu (m.in. prowadzenie dzienników, rejestrów, archiwum spraw i przekazywanie ich do Wydziału „C”, obsługę poczty, zaopatrywanie IOF w materiały biurowe oraz maszynopisanie) oraz za sprawy socjalne (wypłacanie poborów i innych świadczeń, zaopatrywanie w bilety i karty żywnościowe $)^{32}$.

${ }^{30}$ Za: P. Piotrowski, Stużba Bezpieczeństwa w latach 1975-1990, s. 31.

31 AIPN, MSW, 0859/794, Wykaz obsady personalnej Zarządu Ochrony Funkcjonariuszy MSW i ogniw terenowych, Warszawa [1989], k. 219-231. Identyczny z tytułu wykaz pochodzący także z 1989 r. wskazuje na drobne rozbieżności w obsadzie Zespołu IV (zob. AIPN, 0859/735, Wykaz obsady personalnej Zarządu Ochrony Funkcjonariuszy MSW i ogniw terenowych [1989 r.], k. 434).

${ }_{32}$ AIPN Gd, 0046/678, t. 1, poz. 53, Szczegółowy zakres działania Inspektoratu Ochrony Funkcjonariuszy Wojewódzkiego Urzędu Spraw Wewnętrznych w Gdańsku, 26 III 1985, k. 1-10. 
Dla odmiany w poznańskim IOF podział ten między czterech inspektorów wyglądał tak: 1) wydziały SB, MO oraz pracownicy cywilni WUSW, 2) RUSW Poznań, 3) funkcjonariusze i pracownicy cywilni ZOMO oraz kursanci BCP ZOMO, 4) pozostałe RUSW, pozostali pracownicy cywilni oraz Zarząd Zdrowia ${ }^{33}$. Większość IOF nie dysponowała osobnymi etatami dla sekretarek-maszynistek, korzystając z tych zatrudnionych w innych komórkach WUSW. Ocena, czy te rozwiązania organizacyjne (zarówno na poziomie centrali, jak i wojewódzkim) były funkcjonalne, wymaga dalszej analizy.

Dużo więcej jesteśmy w stanie powiedzieć o kadrach ZOF. Według stanu na rok 1989 w centrali (kierownictwo wraz z obsadą wszystkich zespołów) powstało dwadzieścia siedem etatów, a w wojewódzkich inspektoratach sto pięćdziesiąt dwa etaty. Kolejnych dziewięć etatów stworzono przy szkołach resortowych MSW (m.in. ASW, WSO w Legionowie i Szczytnie, szkołach milicyjnych w Słupsku i Pile) ${ }^{34}$. Daje nam to łączną liczbę stu osiemdziesięciu ośmiu etatów.

Ścisłe kierownictwo ZOF w latach 1985-1990 to grupa czterech oficerów. Dyrektorami ZOF byli kolejno:

— płk Jacek Sosnowski (20 XII 1984-1 XI 1987)

— płk Stanisław Dębski (1 XI-18 XII 1987)

— płk Sylwester Gołębiewski (1 II 1988-1 III 1990)

zastępcami zaś:

— płk Stanisław Dębski (20 XII 1984-1 listopada 1987)

— płk Sylwester Gołębiewski (1 XI 1987-1 II 1988)

— płk Zdzisław Nawrocki (16 II 1988-1 III 1990) (35. $^{35}$

Cała trójka dyrektorów to wieloletni funkcjonariusze służb specjalnych cywilnych lub wojskowych. Płk Sosnowski karierę bezpieczniacką rozpoczął już w 1945 r. (referent w PUBP w Pułtusku). Po krótkim kursie oficerskim kilka lat spędził w różnych jednostkach MBP na terenie Warmii i Mazur (m.in. szef PUBP w Ostródzie w latach 1950-1952), a od 1952 r. pracował już w Warszawie. Z krótkimi przerwami (m.in. w 1957 r. Zarząd II SG LWP, a w latach 1970-1972 przekazany „do dyspozycji dyrektora Departamentu I”) całe życie przepracował w Departamencie III, w latach 1980-1984 piastując funkcję zastępcy dyrektora. Płk Gołębiewski po ukończeniu rocznej szkoły oficerskiej w 1954 r. został przeniesiony do Wrocławia, gdzie na różnych stanowiskach operacyjnych pozostał do $1960 \mathrm{r}$. Następnie przeszedł do pionu II (do 1963 r. w Wydziale II KW MO w Katowicach, w latach 1963-1973 w KM MO m.st. Warszawy, a w latach 1973-1985 w centrali). Ponadto w latach 1977-1982 pracował na etacie niejawnym dla Departamentu I, oficjalnie jako I sekretarz Misji Wojskowej PRL w Berlinie, nieoficjalnie jako rezydent wywiadu.

Przyjrzyjmy się teraz kierownikom wojewódzkich inspektoratów ochrony funkcjonariuszy $^{36}$. Rozpiętość wiekowa w tej grupie była znaczna (od rocznika 1924 po rocznik 1949), choć jednocześnie znalazło się w niej jedynie trzech weteranów, którzy kariery w aparacie

\footnotetext{
${ }_{33}$ AIPN Po, 078/2, t. 1, Plan czynności Inspektoratu ochrony Funkcjonariuszy WUSW Poznań na m-c kwiecień 1985, 25 IV 1981, k. 91.

${ }^{34}$ Na podstawie: AIPN, 0859/794, Wykaz obsady personalnej Zarządu Ochrony Funkcjonariuszy MSW i ogniw terenowych [1989 r.], k. 219-231; P. Piotrowski, Obsada kierowniczych stanowisk w aparacie bezpieczeństwa w latach 1975-1990, w: Aparat bezpieczeństwa w Polsce, t. III, s. 72.

${ }^{35}$ Ibidem.

${ }^{36}$ Bliższe dane udało się ustalić w stosunku do trzydziestu pięciu kierowników. Ich pełna liczba przekracza czterdziestu dziewięciu, gdyż co najmniej w kilku przypadkach (np. w gdańskim WUSW) dochodziło do zmiany na stanowisku kierownika IOF; zob. AIPN, 0789/1, t. 2, Zarządzenie
} 
rozpoczynali jeszcze pod koniec lat czterdziestych. Zdecydowana większość z nich urodziła się między 1940 a 1949 r. W trakcie obejmowania stanowiska mieli więc mniej więcej czterdzieści lat. Oznaczało to solidne, kilkunastoletnie doświadczenie służbowe. Zazwyczaj byli to oficerowie w stopniu majora lub podpułkownika, rzadziej kapitana lub pułkownika. Z bardzo nielicznymi wyjątkami mieli wyższe wykształcenie (dotyczyło to także pozostałych funkcjonariuszy ZOF). W zasadzie wejście do ZOF oznaczało awans w oficjalnej hierarchii organizacyjnej: zazwyczaj o jeden szczebel (ze stanowiska zastępcy naczelnika wydziału), ale zdarzały się też bardziej spektakularne ruchy kadrowe, np. ze stanowisk starszych inspektorów bądź kierowników sekcji ${ }^{37}$. Awans przekładał się także na wzrost zarobków: funkcjonariusze przeskakiwali zazwyczaj jeden stopień w tabeli grup uposażenia ${ }^{38}$.

Wśród kierowników IOF brakuje jednej dominującej ścieżki kariery. Mniej więcej połowa miała doświadczenie milicyjne (w tym operacyjne), choć tylko trzech wyłącznie milicyjne. W przybliżeniu połowa miała za sobą pracę operacyjną w SB. Kilku funkcjonariuszy pracowało w strukturach odpowiedzialnych za sprawy dyscyplinarne (piony inspekcji, kadr lub śledcze $)^{39}$. Ogólnie można powiedzieć, że kierownicy IOF byli oficerami o doświadczeniu głównie operacyjnym (z MO lub SB) bądź związanym ze sprawami kadrowo-dyscyplinarnymi, rzadziej z innymi pionami (m.in. obserwacji lub paszportów). Wyjątkami są tu tylko kierownicy z Olsztyna i Torunia. Pierwszy z nich — ppłk Henryk Jarzębowski ${ }^{40}$ niemal całą karierę $\mathrm{w}$ aparacie bezpieczeństwa przepracował na stanowiskach szkoleniowo-administracyjnych, drugi zaś - ppłk Grzegorz Rost - w pionie „T”. W grupie kierowników IOF nie było ani jednego funkcjonariusza wywodzącego się z wojska. Potencjalną grupę totumfackich gen. Kiszczaka tworzą jednak ci, którzy wcześniej przeszli przez pion polityczno-wychowawczy ${ }^{41}$.

Przyjrzyjmy się jeszcze kilku innym funkcjonariuszom z centrali ZOF:

— płk Czesław Królak (rocznik 1942) — starszy specjalista Zespołu I — w aparacie bezpieczeństwa znalazł się w 1965 r., a w SB w 1971 r. Do 1975 r. pracował w Wydziale III KW MO w Łodzi, a w latach 1978-1984 w KW MO w Legnicy, pełniąc m.in. funkcje zastępcy naczelnika Wydziału III „A” oraz naczelnika Wydziału „B”. Zapowiadał się dość przeciętnie, ale już pod koniec lat sześćdziesiątych zbierał dobre opinie jako organizator i oficer operacyjny. W 1982 r. przeszedł przeszkolenie w Wyższej Szkole Komitetu Bezpieczeństwa Państwowego przy Radzie Ministrów ZSRS w Moskwie ${ }^{42}$;

— płk Zygmunt Rybacki (rocznik 1934) — kierownik Zespołu II — w aparacie pracował od 1952 r., m.in. w Wydziałach II, III, IV i Śledczym w Szczecinie, a od 1971 r. w Departamencie III w Warszawie (od 1983 r. jako zastępca naczelnika Wydziału I).

\footnotetext{
organizacyjne nr 0130, b.d., k. 113-118; AIPN, 0859/735, Wykaz obsady personalnej Zarządu Ochrony Funkcjonariuszy MSW i ogniw terenowych [1989 r.], k. 434-441.

${ }^{37} \mathrm{~W}$ gruncie rzeczy za dość wyraźny awans trzeba uznać przypadek kierownika IOF z Białej Podlaskiej, który wcześniej był zastępcą szefa ds. SB w RUSW Parczewo.

${ }^{38}$ Przykładowo, płk Zygmunt Rybacki jako zastępca naczelnika Wydziału I w Departamencie III przyporządkowany był do grupy uposażania 07, a po przejściu do ZOF w styczniu 1985 r. (kierownik Zespołu II) znalazł się w grupie uposażenia 06 (AIPN, 0604/1297, Akta osobowe Zygmunta Rybackiego).

${ }^{39}$ Dotyczyło to kierowników z Białegostoku, Gdańska, Legnicy, Łodzi, Piły i Suwałk.

${ }^{40}$ Ppłk. Jarzębowskiego na stanowisku kierownika olsztyńskiego IOF w sierpniu lub wrześniu 1989 r. zmienił ppłk Ireneusz Szczepański.

${ }^{41}$ Chodziło o kierowników IOF z Bydgoszczy, Leszna, Lublina, Siedlec i Sieradza.

${ }^{42}$ AIPN, 02042/601, Akta osobowe Czesława Królaka.
} 
W czasie całej kariery nie zaliczył poważnych wpadek dyscyplinarnych; przed przejściem do ZOF ceniono zwłaszcza jego umiejętności organizacyjne i analityczne ${ }^{43}$;

— ppłk Lechosław Sobieraj (rocznik 1942) — starszy specjalista Zespołu II i IV — w latach 1964-1986 był funkcjonariuszem MO (jako dzielnicowy, technik dochodzeniowy, zomowiec, a od 1976 r. w Biurze do walki z Przestępczością Gospodarczą w KG MO). Przez całą karierę świetnie go oceniano, dostrzegano jego umiejętności organizacyjne i interpersonalne, samodzielność i pomysłowośćc4;

— ppłk Włodzimierz Tokarz (rocznik 1941) — starszy specjalista Zespołu II — karierę w resorcie rozpoczął w 1963 r. od pracy w milicyjnej Izbie Dziecka w Bydgoszczy i z tego okresu opinie służbowe były dla niego dość krytyczne. Rozwinął się w Wydziale III KW MO w Bydgoszczy (lata 1969-1973). Do ZOF przeszedł bezpośrednio z Wyższej Szkoły Oficerskiej im. F. Dzierżyńskiego w Legionowie, gdzie wykładał w latach 1973-198545;

— płk Adam Burdal (rocznik 1931) — kierownik Zespołu IV — był funkcjonariuszem z ponad dwudziestopięcioletnim stażem, na który złożyła się przede wszystkim praca operacyjna w pionie III (początkowo w KW MO w Gdańsku, potem w centrali). Od połowy lat siedemdziesiątych do 1982 r. pracował w Wydziale VIII Departamentu III, gdzie jego zwierzchnikiem był płk Jacek Sosnowski, przyszły dyrektor $\mathrm{ZOF}^{46}$.

Inspektoraty dysponowały zróżnicowaną liczbą etatów, co wynikało zapewne zarówno $\mathrm{z}$ rangi danego województwa (np. występowanie dużych aglomeracji miejskich, ośrodków przemysłowych, stała obecność obcokrajowców, zwłaszcza z krajów kapitalistycznych), jak i liczby zatrudnionych w danym WUSW pracowników. Według danych z 1989 r. najmniej liczne obsady inspektoratów (po dwa etaty: kierownik i funkcjonariusz na stanowisku starszego inspektora) miały struktury w WUSW w: Białej Podlaskiej, Bielsku-Białej, Chełmie, Ciechanowie, Koninie, Krośnie, Lesznie, Łomży, Ostrołęce, Pile, Przemyślu, Sieradzu, Skierniewicach, Słupsku i Zamościu. Do najliczniej obsadzonych należały IOF w strukturach WUSW w Gdańsku i Katowicach (siedem etatów: kierownik, pięciu starszych inspektorów oraz sekretarka-maszynistka), w SUSW (sześć etatów: kierownik i pięciu starszych inspektorów) oraz w Krakowie, Łodzi, Poznaniu i Szczecinie (pięć etatów: kierownik i czterech starszych inspektorów) $)^{47}$.

Charakterystyka funkcjonariuszy IOF jest podobna jak oficerów z centrali: stosunkowo długi staż (mniej więcej dziesięcioletni), doświadczenie milicyjne, esbeckie (operacyjne) lub w pionach śledczych, kontrolnych i kadr, a w niektórych przypadkach także ukończone kursy KGB (np. mjr Sylwester Górny z Leszna, kpt. Zbigniew Grudzień z Wałbrzycha oraz ppłk Jerzy Pilitowski z Gorzowa Wielkopolskiego). Z gdańskich funkcjonariuszy IOF na szczególną uwagę zasługuje Edmund Mucha (rocznik 1948). W 1971 r. wstąpił do MO. Pracował w pionie walki z przestępczością gospodarczą (początkowo w KM MO w Gdyni, a od 1977 r. w KW MO w Gdańsku). Przed przejściem do IOF sprawował funkcję kierownika sekcji de-

\footnotetext{
${ }^{43}$ Ibidem, 0604/1297, Akta osobowe Zygmunta Rybackiego.

${ }^{44}$ Ibidem, 0604/1865, Akta osobowe Lechosława Sobieraja.

${ }^{45}$ Ibidem, 0604/1566, Akta osobowe Włodzimierza Tokarza.

${ }^{46}$ Ibidem, 0604/1302, Akta osobowe Adama Burdala.

${ }^{47}$ Ibidem, 0859/794, Wykaz obsady personalnej Zarządu Ochrony Funkcjonariuszy MSW i ogniw terenowych [1989 r.], k. 219-231. W dwóch innych wykazach obsady (z 1984 r. i 1989 r.) znaleźć można pewne drobne różnice co do liczby etatów w poszczególnych IOF (zob. ibidem, 0859/735, Wykaz obsady personalnej Zarządu Ochrony Funkcjonariuszy MSW i ogniw terenowych [1989 r.], k. 435-439; ibidem, 0789/1, t. 2, Zarządzenie organizacyjne nr 0103/org z 27 XII 1984, k. 113-118).
} 
wizowej. W międzyczasie ukończył WSO w Szczytnie oraz zdobył dyplom magistra administracji na Uniwersytecie Gdańskim. Przez całą karierę oceniany był bardzo dobrze. Chwalono jego umiejętności organizatorskie i operacyjne, nie był karany dyscyplinarnie. W gdańskim Inspektoracie w listopadzie 1987 r. awansował na stanowisko p.o. kierownika (od stycznia 1989 r. był już ,pełnym” kierownikiem), a w 1988 r. nadano mu stopień majora ${ }^{48}$. To jeszcze jeden przypadek wysokiej jakości kadr ZOF.

\section{Procedury i środki działania ZOF}

Funkcjonowanie ZOF definiowało głównie Zarządzenie nr 0073/84 ministra Kiszczaka, oprócz tego także normatywy pomniejszej rangi ${ }^{49}$. Pracę Zarządu rozpoczynało postępowanie wyjaśniające, inicjowane informacją od kierowników jednostek i komórek organizacyjnych resortu, którzy mieli obowiązek informować o podejrzeniu popełnienia nadużyć lub przestępstw (§ 1 Zarządzenia). W praktyce część spraw wszczynana była także wskutek anonimów. W trakcie postępowania wyjaśniającego nie wolno było stosować metod operacyjnych oraz podejmować czynności procesowych. Analizowano informacje o wykroczeniu, dokumenty, przeprowadzano rozmowy z funkcjonariuszem, jego kolegami, przełożonymi lub pokrzywdzonymi, wykorzystywano wstępne opinie rzeczoznawców lub wyniki kontroli i sprawdzeń. Na poziomie wojewódzkim postępowanie wyjaśniające mogło być prowadzone siłami IOF lub zlecane na zewnątrz (np. szefowi RUSW). Po tym czasie kierownik IOF sporządzał sprawozdanie, w którym: 1) decydował o zamknięciu postępowania (zarzut nie potwierdzał się, funkcjonariusz był oczyszczany z podejrzeń); 2) wnioskował o wszczęcie postępowania dyscyplinarnego lub przygotowawczego (sprawę przejmował pion śledczy, kadry lub przełożeni); lub 3) wnioskował o założenie sprawy operacyjnej dla dalszego pogłębienia informacji. W tym ostatnim przypadku wniosek przedkładano szefowi WUSW i zastępcy szefa WUSW ds. polityczno-wychowawczych (względnie komendantowi szkoły, dyrektorowi ośrodka szkoleniowego lub dyrektorowi Centralnego Szpitala Klinicznego MSW, jeśli postępowanie było prowadzone na tym terenie). Jeśli dochodziło do rozbieżności zdań, sprawę przejmował ZOF i podejmował decyzję o formie i kierunkach dalszego postępowania. W przypadku zgodności IOF inicjował sprawę operacyjną zgodnie z nomenklaturą i procedurami zdefiniowanymi w Instrukcji o pracy operacyjnej z 1970 r. Postępowanie miało kończyć się w ciągu miesiąca, w uzasadnionych przypadkach mogło być wydłużone do trzech miesięcy. Gdy także po tym czasie nie zostało zakończone, całość dokumentacji przesyłano do dyrektora ZOF, ten zaś mógł je przedłużyć w niektórych sytuacjach na czas nieokreślony (zob. schemat $\mathrm{nr} 1$ ).

$\mathrm{Na}$ poziomie centrali w sprawach prowadzonych wobec funkcjonariuszy MSW lub też funkcjonariuszy pozostających w kompetencjach personalnych ministra spraw wewnętrznych (względnie szefa Służby Kadr) procedura wyglądała analogicznie, z tym że wniosek o wszczęcie sprawy operacyjnej kierowano do szefa Służby Zabezpieczenia Operacyjnego MSW (nadzorującego piony „,B”, „,C”, „,T” i ,W”) oraz szefa służby nadzorującego daną jed-

\footnotetext{
${ }^{48}$ Ibidem, 1756/644, Akta osobowe Edmunda Muchy.

${ }^{49}$ Zob. AIPN Po, 078/2, t. 1, Zasady prowadzenia postępowań wyjaśniających w pionie ochrony funkcjonariuszy MSW, 21 V 1987 r., k. 396-399; ibidem, Ramowy zakres działania Inspektoratów Ochrony Funkcjonariuszy WUSW i starszych inspektorów ochrony funkcjonariuszy w szkołach, ośrodkach szkolenia MSW i CSK MSW, 22 II 1985 r., k. 82-87; AIPN, 55/18, Zarządzenie nr 0073/84 ministra spraw wewnętrznych z dnia 27 grudnia 1984 r. w sprawie uprawnień oraz metod i środków pracy pionu ochrony funkcjonariuszy i pracowników cywilnych, k. 64-68.
} 
nostkę. ZOF mógł także zlecić IOF działania sprawdzające lub operacyjne w odniesieniu do innych funkcjonariuszy lub też inne zadania wynikające z uprawnień ZOF.

Jak wyglądały operacyjne środki działań ZOF? § 3 pkt. 1 Zarządzenia nr 0073/84 stanowił, że ,pion ochrony funkcjonariuszy, w podejmowanych działaniach stosuje wszelkie metody i środki pracy operacyjnej według zasad obowiązujących Służbę Bezpieczeństwa i Milicję Obywatelską" ${ }_{50}$. Funkcjonariusze ZOF mieli więc m.in. pełne możliwości korzystania $\mathrm{z}$ instrumentarium pionu ,T”, „B” i ,W”. Żadna inna struktura kontrolna w łonie MSW nie miała takich uprawnień, a rzecz nie kończyła się na podsłuchach, niejawnej obserwacji i perlustracji. W Zarządzeniu nr 0073/84 czytamy też o możliwości werbowania tajnych współpracowników. I choć § 4 Zarządzenia precyzował, że ZOF nie może dokonywać werbunku wśród funkcjonariuszy, to przewidziano tutaj dwa wyjątki. Po pierwsze, zakaz ten nie dotyczył funkcjonariuszy odbywających służbę wojskową w Batalionach Centralnego Podporządkowania ZOMO. Po drugie, „w szczególnie uzasadnionych przypadkach” można było pozyskiwać w charakterze TW (i wyłącznie na materiałach kompromitujących) regularnych funkcjonariuszy MSW. Sytuacja taka oznaczała dla zwerbowanego zwolnienie ze służby (z zachowaniem uprawnień emerytalnych $)^{51}$.

Stan zachowania dokumentów nie pozwala w sposób systematyczny zbadać funkcjonowania sieci agenturalnej ZOF. W poznańskim IOF werbowano głównie kursantów-poborowych $^{52}$ z BCP ZOMO (piętnastu z siedemnastu zarejestrowanych TW) ${ }^{53}$. Nawiasem mówiąc, proces werbunku wyglądał $\mathrm{w}$ zasadzie niemal podręcznikowo. Jedyny problem wynikał ze specyficznego kontekstu organizacyjnego. Kursanci byli skoszarowani, przez większą część dnia zazwyczaj w pobliżu przebywał jakiś oficer dyżurny, trudno było więc w tajemnicy utrzymywać proces pozyskiwania, a potem regularnych kontaktów. Kursantów oficjalnie werbowano dla „kontrwywiadowczego zabezpieczenia jednostki BCP”, co w praktyce oznaczało informowanie o drobnych kradzieżach wśród kursantów, kradzieży pałek i miotaczy gazu RMG, nagannych zachowaniach dowódców kompanii, pijaństwie, wychodzeniu z jednostki bez przepustki itd. Dwóch zwerbowanych kursantów rozpracowywało kolegów, którzy po skończeniu służby w ZOMO zamierzali pozostać w MO i starali się o skierowanie do WSO w Szczytnie ${ }^{54}$. Wszystkich zwerbowanych kursantów po zakończeniu służby w ZOMO wyrejestrowywano. W pozostałych dwóch przypadkach agentury (spoza ZOMO) pierwszy jest o tyle interesujący, że kandydatka na TW była żoną kapitana MO. Funkcjonariusze IOF spodziewali się, że ta okoliczność może wywołać częściową dekonspirację źródła. Uznali więc, że przed złożeniem propozycji współpracy należy porozmawiać najpierw z jej mężem. Ten z kolei miał uprzedzić żonę o zamiarze ,prowadzenia dialogu" ${ }^{55}$. Żona, zarejestrowa-

\footnotetext{
${ }^{50}$ AIPN, 55/18, Zarządzenie nr 0073/84 ministra spraw wewnętrznych z dnia 27 grudnia $1984 \mathrm{r}$. w sprawie usprawnień oraz metod i środków pracy pionu ochrony funkcjonariuszy i pracowników cywilnych, k. 66.

${ }^{51}$ Ibidem, k. 67.

${ }^{52}$ Istniała możliwość odbycia obowiązkowej służby wojskowej w oddziałach ZOMO.

${ }_{53}$ Według ustaleń Tomasza Błaszaka szczeciński IOF zarejestrował w czasie swojego funkcjonowania aż pięćdziesięciu czterech TW, choć również tam trudno o jakiekolwiek bliższe informacje na temat współpracowników i charakteru tej współpracy (T. Błaszak, Inspektorat Ochrony Funkcjonariuszy WUSW w Szczecinie 1984-1990, referat na konferencji naukowej „Przestępczość funkcjonariuszy MBP i MSW”, IPN, Szczecin, 21-22 V 2014 r.). Z kolei dziennik sieci agenturalnej nowosądeckiego IOF dla lat 1986-1990 zawiera informacje o zaledwie czterech zwerbowanych TW (AIPN Kr, 061/141).

${ }^{54}$ AIPN Po, 078/1, t. 2, 5, 9, 12-23, 26, 73.

${ }_{55}$ Ibidem, 078/1, t. 3, Notatka służbowa z przeprowadzonej rozmowy operacyjnej z kpt. A. Koniecznym (mężem kandyd. na TW), 16 X 1987 r., k. 23.
} 


\section{Schemat nr 1}

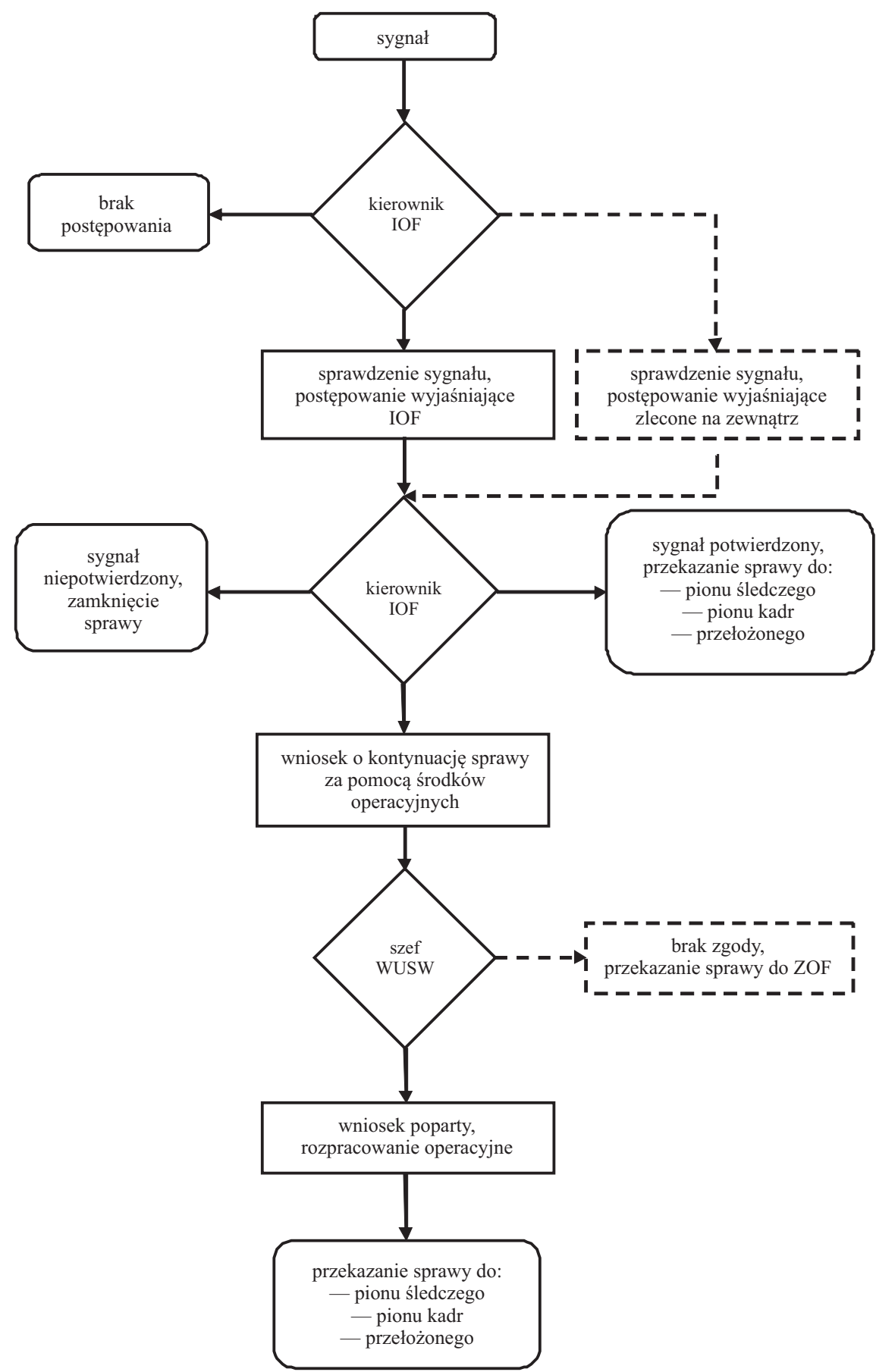

Źródło: opracowanie własne na podstawie: AIPN Po, 078/2, t. 1, k. 82-87; k. 396-399; ibidem, 55/18, k. 64-68. 
na jako TW „Ania”, oprócz wykorzystania w SOR krypt. „Żeglarz” (podejrzenie o łapówkarstwo funkcjonariusza Wydziału Paszportów WUSW w Poznaniu) miała także rozpoznać nastroje wśród pracowników cywilnych Polikliniki WUSW. W drugim przypadku chodziło o wiceprezesa spółdzielni mieszkaniowej (zarejestrowanego jako TW „Edmund”), wykorzystywanego w SOR krypt. „Mirosław” (podejrzenie płatnej protekcji pracownika Urzędu Wojewódzkiego powołującego się na wpływy w Wydziale Paszportowym WUSW) ${ }^{56}$. W dokumentach poznańskiego IOF zachowała się też teczka pracy KO „Michał”, którego planowano wykorzystywać w sprawach korumpowania funkcjonariuszy przez ,,przedstawicieli sektora prywatnego" "57. W przeanalizowanych dotąd sprawach nie natknęliśmy się na żaden przypadek tajnego współpracownika-funkcjonariusza.

\section{Obraz funkcjonowania ZOF i aparatu MSW w świetle dokumentów}

Trudno precyzyjnie scharakteryzować działalność ZOF oraz jego ustalenia dotyczące skali i natury wykroczeń w MSW. Chodzi nie tylko o różny stan zachowania dokumentów, ale też o prowadzenie ewidencji operacyjnej ZOF (funkcjonującej niezależnie od pionu „C”). Sprawy rejestrowano na trzech kartach: A, B i C. Każda z nich zawierała imię, nazwisko i stopień sprawdzanej osoby, rubrykę Krótki opis sytuacji, zdarzenia oraz informację o sposobie zakończenia sprawy. Dodatkowo na pierwszej karcie znajdowały się szczegółowe dane o sprawdzanym funkcjonariuszu, na drugej o klasyfikacji sprawy, na trzeciej zaś o zastosowanych przedsięwzięciach operacyjnych. Kluczowa była tu karta B wraz z przyjętym indeksem zagrożeń. Wyróżniono tam sześć typów „naruszeń prawa i czynów szkodliwych”:

— działalność przeciwko podstawowym interesom PRL;

— infiltracja resortu spraw wewnętrznych (przez przeciwnika politycznego, środowiska przestępcze, obce służby specjalne, inne grupy, środowiska i organizacje);

— przestępstwa kryminalne i gospodarcze;

— naruszanie zasady tajemnicy służbowej i państwowej;

— nadmierne i nieuzasadnione bogacenie się;

- inne.

Według ustaleń Izabeli Kuny w niektórych IOF zarzutów nie kwalifikowano skrupulatnie, wykorzystując wygodną kategorię ,inne" ${ }^{58}$. Poza tym powyższa typologia jest nieprecyzyjna z metodologicznego punktu widzenia (m.in. nie spełnia kryterium rozłączności). Poszczególne sprawy mogły być klasyfikowane zależnie od interpretacji. Wszystkim typom działań mogło towarzyszyć ,nadmierne bogacenie się”. Z tego zresztą względu w rocznych zestawieniach ZOF po 1985 r. zrezygnowano z równie chybionej kategorii „wykorzystanie stanowiska do uzyskania korzyści materialnych" ${ }^{59}$. Dodatkowo typologia stosowana na kartach B nie była jedyną stosowaną w sprawozdawczości ZOF. Wytyczne dotyczące przesyłania informacji do Departamentu Kadr o ważniejszych przewinieniach funkcjonariuszy, które w 1985 r. otrzymali kierownicy jednostek organizacyjnych resortu (w tym kierownicy IOF), wyróżniały pięć typów: wydarzenia nadzwyczajne, wydarzenia kwalifikujące się do

\footnotetext{
${ }^{56}$ Ibidem, 078/1, t. 24-25 (teczka personalna i teczka pracy TW „Edmund”).

57 Ibidem, 078/1, t. 1 (teczka pracy KO „Michał”).

${ }^{58}$ I. Kuna, Inspektoraty Ochrony Funkcjonariuszy Wojewódzkich Urzędów Spraw Wewnętrznych pótnocno-wschodniej Polski (1984-1990). Struktury, kadry, działalność, referat na konferencji naukowej „Przestępczość funkcjonariuszy MBP i MSW”, IPN, Szczecin, 21-22 V 2014 r.

59 AIPN, 0789/1, t. 1, Liczbowa charakterystyka działalności pionu ochrony funkcjonariuszy w latach 1985-1989, k. 222.
} 
kolegium ds. wykroczeń, poważniejsze naruszenia dyscypliny służbowej, czynną napaść na funkcjonariusza oraz obrazę funkcjonariusza. Z punktu widzenia spraw dyscypliny w MSW kluczowe zdają się tu dwie kategorie: wydarzenia nadzwyczajne i poważniejsze naruszenia dyscypliny. Obie z kolei zawierały dalsze szczegółowe podtypy ${ }^{60}$. To jednak nie koniec, gdyż od października 1987 r. obowiązywało zarządzenie ministra spraw wewnętrznych regulujące m.in. niektóre sprawy związane z postępowaniami dyscyplinarnymi, które wyróżniało czternaście różnych kategorii naruszania dyscypliny. Uwzględniono tam wykroczenia poważne (np. wykorzystywanie stanowiska dla osiągnięcia prywatnej korzyści lub zagubienie/utratę dokumentów stanowiących tajemnicę służbową/państwową), jak i względnie mało ważne (np. symulację choroby i zawinioną utratę legitymacji służbowej) ${ }^{61}$. Reasumując, trudno o precyzyjny obraz funkcjonowania MSW z perspektywy ZOF, jeśli tworzyły go niejednolite i nieprzemyślane pod względem hierarchizacji spraw ramy kategorialne (do tego wątku jeszcze wrócimy).

Mając świadomość powyższych zastrzeżeń, ustalenia Kuny w odniesieniu do województwa olsztyńskiego na podstawie działalności tamtejszego IOF w latach 1985-1989 pokazują następujący rozkład przypadków naruszeń prawa:

- 19 proc. infiltracja resortu przez przeciwnika politycznego;

- 18 proc. przestępstwa kryminalne;

- 17 proc. czerpanie korzyści majątkowych i nieuzasadnione bogacenie się;

- 15 proc. naruszenie zasad tajemnicy służbowej;

- 11 proc. infiltracja resortu przez środowiska przestępcze;

- 3 proc. przestępstwa gospodarcze;

-17 proc. inne ${ }^{62}$.

Uwagę zwraca nieobecność kategorii „działalność przeciwko interesom PRL” (podobnie w naszych analizach) oraz względnie duża liczba przypadków kwalifikowanych jako „inne”.

Ogólne światło na efekty działalności ZOF rzucają jego roczne sprawozdania. Wyraźnie pokazują one skalę działania Zarządu. Każdego roku ZOF otrzymywał informacje o mniej więcej 500 sprawach, z których następnie 80 proc. wyjaśniano. Dotyczyły one rocznie około 670 funkcjonariuszy i pracowników cywilnych MSW. Najczęstsze przypadki to przestępstwa kryminalne i gospodarcze oraz różnego rodzaju przewinienia służbowe. Najpoważniejszym skutkiem działań podejmowanych przez ZOF było, z jednej strony, wyrzucanie z resortu (średnio 160 funkcjonariuszy na rok) oraz tymczasowe aresztowania przez prokuraturę ('średnio nieco ponad 30 rocznie; zob. tabela nr 1), z których część kończyła się później prawomocnymi wyrokami skazującymi.

\footnotetext{
${ }^{60}$ Wśród wydarzeń nadzwyczajnych były to: przestępstwa, samobójstwa usiłowane/dokonane, zagubienie/utrata dokumentów służbowych, użycie/utrata broni służbowej, nieszczęśliwe wypadki (ciężkie uszkodzenia ciała, znaczne straty majątku), inne wydarzenia pociągające za sobą postępowanie karne, wśród poważniejszych naruszeń dyscypliny zaś: zatajanie kontaktów (własnych lub rodziny) z osobami stale przebywającymi w krajach kapitalistycznych lub organizacjami z tych krajów, spożywanie alkoholu w służbie lub w pomieszczeniach służbowych, odmowa wykonania polecenia służbowego, znieważenie przełożonego, wypadki drogowe spowodowane przez funkcjonariuszy w stanie nietrzeźwości oraz symulacja choroby w celu uchylania się od pracy (ibidem, 0859/735, Notatka w sprawie nadsyłanych informacji o ważniejszych przewinieniach funkcjonariuszy MO i SB [1985 r.], k. 82-84).

${ }^{61}$ AIPN Po, 078/2, t. 1, Zarządzenie nr 61/87 Ministra Spraw Wewnętrznych z dnia 31 października 1987 r. w sprawie udzielania wyróżnień oraz postępowania dyscyplinarnego, k. 527-528.

${ }^{62}$ I. Kuna, Inspektoraty Ochrony Funkcjonariuszy Wojewódzkich Urzędów Spraw Wewnętrznych.
} 
Kolejna rzecz rzucająca się w oczy to duże zróżnicowanie liczby nadużyć w poszczególnych WUSW. Przykładowo, w latach 1985-1989 olsztyński IOF przeprowadził dziewięćdziesiąt cztery postępowania, a także trzy SOR i dwa SOS, łomżyński — czterdzieści dziewięć postępowań (przy braku spraw operacyjnych) ${ }^{63}$, a poznański — czterdzieści siedem postępowań oraz siedem SOR i dwa $\mathrm{SOS}^{64}$. Zwróćmy przy tym uwagę, że częściowo mamy tu do czynienia z niedopasowaniem struktur do wyzwań. O ile niezmiennie ośrodkami o najwyższej liczbie przewinień pozostawały Warszawa i Gdańsk (przodujące także w liczbie zatrudnionych funkcjonariuszy IOF), o tyle w przypadku innych WUSW mieliśmy do czynienia z nad- lub niedoreprezentowaniem spraw w stosunku do liczebności IOF. Przykładowo, wśród najbardziej niezdyscyplinowanych struktur wojewódzkich ledwie raz (w 1985 r.) znalazł się katowicki WUSW, którego IOF był jednym z najliczniejszych. Dla odmiany niska dyscyplina regularnie dotyczyła WUSW w Tarnobrzegu, w którym komórka IOF była dość słabo obsadzona (trzech funkcjonariuszy) ${ }^{65}$.

Jak te dane mają się do całościowego obrazu dyscypliny w MSW? Przede wszystkim Zarząd zajmował się jedynie niewielką częścią przewinień w stosunku do wszystkich tego typu zdarzeń rejestrowanych przez MSW (por. tabela nr 2). W pewnym sensie było to zgodne z pierwotnymi założeniami dotyczącymi działania ZOF - miał się on zajmować jedynie poważnymi przypadkami (o czym dalej). Wagę tych przypadków wyraźnie widać, biorąc pod uwagę proporcje między analizowanymi sprawami a liczbą wydaleń ze służby. W $1985 \mathrm{r}$. w całym MSW odnotowano 7152 przewinienia, skutkiem czego z aparatu wyrzucono łącznie 726 funkcjonariuszy i pozostałych pracowników MSW ${ }^{66}$. A zatem (upraszczając): co dziesiąte przewinienie kończyło się wyrzuceniem. W przypadku ZOF proporcje były nieco inne: w 1985 r. każda co szósta prowadzona sprawa kończyła się wyrzuceniem, a w kolejnych latach wskaźnik ten jeszcze wzrósł (średnio każdy co trzeci przypadek).

Tabela nr 2

\begin{tabular}{|l|r|r|r|r|r|r|}
\hline \multicolumn{1}{|c|}{ Rodzaj dzialalności } & \multicolumn{7}{c|}{ Lata } & \multirow{2}{*}{ Razem } \\
\cline { 2 - 8 } & $\mathbf{1 9 8 5}$ & $\mathbf{1 9 8 6}$ & $\mathbf{1 9 8 7}$ & $\mathbf{1 9 8 8}$ & $\mathbf{1 9 8 9}$ & \\
\hline 1. Informacje do wyjaśnienia - ogółem & 530 & 738 & 520 & 510 & 261 & 2579 \\
\hline 2. Informacje wyjaśnione - ogółem & 321 & 553 & 435 & 489 & 259 & 2075 \\
\hline 3. Liczba funkcjonariuszy i pracowników & 604 & 1005 & 705 & 673 & 387 & 3374 \\
cywilnych objętych wyjaśnieniami - ogółem & & \\
\hline 4. Rodzaj zagrożeń, wobec których podjęto działania (wybrane) ${ }^{*}:$ \\
- podejmowane kontakty z elementem
\end{tabular}

63 Ibidem.

${ }^{64}$ AIPN Po, 06/274, Spis akt [IOF WUSW Poznań] przekazanych nr 357 do Wydziału „C” WUSW w Poznaniu w dniu 13 II 1990 r., k. 5-7.

${ }_{65}$ Dane na podstawie: AIPN, 0789/1, t. 1.

${ }^{66}$ Dane na podstawie: ibidem, Informacja o stanie dyscypliny i przewinieniach służbowych popełnionych przez funkcjonariuszy MO i SB w wojewódzkich urzędach spraw wewnętrznych w 1985 roku, 27 III 1986 r., k. 73-83. 


\begin{tabular}{|c|c|c|c|c|c|c|}
\hline \multirow{2}{*}{ Rodzaj działalności } & \multicolumn{5}{|c|}{ Lata } & \multirow{2}{*}{ Razem } \\
\hline & 1985 & 1986 & 1987 & 1988 & 1989 & \\
\hline \multicolumn{7}{|l|}{ 5. Skutki likwidacji zagrożeń: } \\
\hline $\begin{array}{l}\text { a) wyprowadzenie i zwolnienie } \mathrm{z} \text { resortu } \\
\text { funkcjonariuszy i pracowników cywilnych }\end{array}$ & 80 & 134 & 181 & 193 & 214 & 802 \\
\hline b) tymczasowe aresztowanie przez prokuratury & 17 & 41 & 29 & 58 & 13 & 158 \\
\hline c) działania dyscyplinujące, w tym: & 155 & 306 & 244 & 236 & 249 & 1190 \\
\hline $\begin{array}{l}\text { - przeniesienie do innej jednostki albo na inne } \\
\text { stanowisko służbowe }\end{array}$ & 29 & 24 & 55 & 51 & 34 & 193 \\
\hline — kara dyscyplinarna & 55 & 87 & 85 & 66 & 89 & 382 \\
\hline $\begin{array}{l}\text { — rozmowy i inne działania profilaktyczno- } \\
\text { ostrzegawcze }\end{array}$ & 71 & 195 & 104 & 119 & 126 & 615 \\
\hline $\begin{array}{l}\text { 6. Liczba oczyszczonych z zarzutów } \\
\text { funkcjonariuszy i pracowników cywilnych }\end{array}$ & 105 & 240 & 252 & 249 & 192 & 1038 \\
\hline
\end{tabular}

* W 1985 r. podziału nie dokonano

Źródło: AIPN, MSW, 0789/1, t. 1, k. 222.

Analitycy ZOF dostrzegali strukturalny kontekst niektórych przewinień, wiążący się z istotną zmianą systemu gospodarczego PRL w latach osiemdziesiątych. Chodziło o rozwój tzw. sektora nieuspołecznionego, w tym m.in. spółek polonijnych ${ }^{67}$. W sprawozdaniu ZOF za rok 1988 czytamy: „Głównym motywem przestępczej działalności wśród funkcjonariuszy była chęć osiągania korzyści materialnej. W związku z sytuacją polityczną i ekonomiczną, rozwijaniem się sektora prywatnego i spółek zagranicznych można prognozować, że zjawisko przestępczości wśród funkcjonariuszy i pracowników resortu spraw wewnętrznych może co najmniej utrzymać się na poziomie 1988 roku, stąd też niezbędnym staje się wymóg zwiększania uwagi przełożonych służbowych na zachowanie i działalność przedstawicieli resoru realizujących zadania w stosunku do elementu przestępczego oraz ochranianych przedsiębiorstw gospodarczych i handlowych"68. Tu dodajmy, że w 1988 r. Zarząd PolitycznoWychowawczy rozsyłał pośród swoich inspektorów specjalną ankietę do zbierania informacji o powiązaniach rodzin funkcjonariuszy z sektorem nieuspołecznionym ${ }^{69}$.

${ }^{67}$ Wskazać tu można także inne elementy potencjalnie wpływające na ten kontekst: stopniową liberalizację polityki paszportowej od końca lat osiemdziesiatych $\mathrm{w}$ połączeniu $\mathrm{z}$ rygorystyczną polityką paszportową wobec funkcjonariuszy oraz stopniową pauperyzację funkcjonariuszy wiążącą się choćby z coraz bardziej niekorzystną relacją zarobków do przeciętnego wynagrodzenia. Wymaga to oczywiście dalszej precyzyjnej analizy. Gdyby jednak te na razie hipotetycznie zarysowane okoliczności były prawdziwe, można by powiedzieć, że funkcjonariusze MSW, dotąd względnie (lub wyraźnie) uprzywilejowani wobec innych grup zawodowych w PRL, tracili tę wyróżnioną pozycję. Co więcej, nagroda $\mathrm{w}$ postaci wysokich zarobków i innych premii przestała być czynnikiem przyciągającym do pracy w aparacie bezpieczeństwa lub/i zachęcającym do porządnej pracy. Uzupełnieniem tej hipotezy byłaby także symbolicznie i emocjonalnie trudna do zaakceptowania przez funkcjonariuszy świadomość istnienia ZOF — „policji w policji”. W tym kontekście ważna jest następująca obserwacja Piotra Milczanowskiego (choć ograniczona do „prowincjonalnych” funkcjonariuszy w samej końcówce lat osiemdziesiątych): „Inwigilacja funkcjonariuszy, trudna sytuacja gospodarcza PRL, pogarszające się warunki życia, a przede wszystkim dokonujące się zmiany polityczne pogłębiały frustracje i niepokoje wśród prowincjonalnych pracowników resortu, od których — według ich zdania — nadal dużo wymagano, a na niewiele pozwalano" (Morale funkcjonariuszy SB i MO, s. 655).

${ }^{68}$ AIPN, 0789/1, t. 1, Sprawozdanie z działalności Zarządu Ochrony Funkcjonariuszy MSW i jego odpowiedników w WUSW w 1988 r., 28 I 1989 , k. 112.

${ }^{69}$ Oprócz funkcjonariuszy chodziło także o ich małżonków, dzieci i rodziców. Wyszczególniono tam 
Dlaczego sektor prywatny stanowił problem dla dyscypliny pracowników MSW? Wskazuje na to Andrzej Zybertowicz, tak charakteryzując perspektywę funkcjonowania przedsiębiorców prywatnych w PRL: ,Dla «prywaciarzy» niezbędne były kontakty z administracją państwową [...], z licznymi podmiotami kontrolnymi, z organami ścigania i wymiaru sprawiedliwości [...], z aparatem partyjnym [...], ze środowiskami sportowymi (kluby sportowe oraz koła łowieckie, podobnie jak dziś, były dogodnym miejscem mnożenia kapitału społecznego - tj. fraternizacji «prywaciarzy» z milicjantami, prokuratorami etc.). Wszystko to było przetkane sieciami tajnych współpracowników — w zależności od sektora gospodarki — służb cywilnych bądź wojskowych"70. Skuteczne działanie ,prywaciarza” uzależnione było od działań funkcjonariuszy na kilku co najmniej polach. Esbecy podejmowali bezpośrednie decyzje paszportowe. Rekomendowali także (bądź zgłaszali zastrzeżenia) decyzje urzędów wojewódzkich o zgodzie na prowadzenie działalności gospodarczej, co wynikało z ich wiedzy płynącej z kontroli operacyjnej.

Jak wymiar ten ukazywały sprawy prowadzone przez ZOF? Oto kilka przykładów:

— ppłk Jan Sołtys z Departamentu V utrzymywał bliskie kontakty z ob. RFN Momcilo Filipovičem, właścicielem firmy polonijnej „Lenex”, w której według ustaleń Urzędu Skarbowego dochodziło do nadużyć gospodarczych. Filipovič zatrudnił w firmie syna ppłk. Sołtysa, a potem załatwił mu pracę w RFN. W firmie tej pracował także emerytowany oficer MSW, którego żona w tym czasie pracowała w Biurze „C”. Ponadto ppłk Sołtys bez uzasadnienia kontaktował się z oficerem Wydziału II SUSW ppor. Bogdanem Bobrowiczem, który zwerbował kochankę Filipoviča (rejestrowaną jako TW „Ewa Wiśniewska”). Nalegał na ppor. Bobrowicza, aby odstąpił od operacyjnego wykorzystania tej kobiety. Mimo tych faktów sprawa od strony dyscyplinarnej zakończyła się w zasadzie niczym. Uznano m.in., że naciski ppłk. Sołtysa na ppor. Bobrowskiego były tylko ,poinformowaniem go” w dobrej wierze, że TW „Ewa Wiśniewska" jest zdekonspirowana ${ }^{71}$;

— ppłk Ryszard Janczura oraz mjr Jerzy Stokowski ze stołecznego Wydziału V-1 byli podejrzewani o żądanie kilkumilionowej łapówki od Jana Załuski, pełnomocnika przedsiębiorstwa zagranicznego „Carpatia”. Zarzuty te się nie potwierdziły, ale sprawa ujawniła cały patologiczny splot między Załuską a SB. Wskutek sprawy prowadzonej przez Wydział V-1 SUSW oraz kontroli stołecznego Wydziału Inspekcji okazało się, że „Carpatia” angażuje się w przestępstwa skarbowe, a sam Załuska prawdopodobnie korumpuje funkcjonariuszy MSW i prokuratorów. Ponadto dla ochrony swojej działalności wykorzystywał fakt, że w latach 1984-1986 był zarejestrowanym kontaktem operacyjnym Departamentu I, a w latach 1969-1984 pozostawał na kontakcie Wydziału II KS MO/SUSW w charakterze TW. Nadużycia Załuski usprawiedliwiano jednak korzyściami operacyjnymi. Dokumenty ZOF wskazują też na kontakty i wymianę przysług między Załuską a co najmniej dziesięcioma wysokimi rangą funkcjonariuszami i byłymi funkcjonariuszami zarówno MSW, jak i LWP (m.in. ppłk Marian Węcławiak, ówczesny szef Wydziału „B” SUSW, ppłk Czesław Dmytrzak, ówcze-

prywatne firmy usługowe, handlowe, produkcyjne (także o charakterze rolnym — sady, szklarnie, pieczarkarnie), tzw. małą gastronomię, obsługę ruchu turystycznego, firmy polonijne i zagraniczne oraz właścicieli użytków rolnych (ibidem, 1593/456, Pismo dyrektora Zarządu Polityczno-Wychowawczego gen. brygady Eugeniusza Grabowskiego, 2 VIII 1988, k. 1-3).

${ }^{70}$ A. Zybertowicz, Przemoc „układu” - na przyktadzie sieci biznesowej Zygmunta Solorza, w: Transformacja podszyta przemoca. O nieformalnych mechanizmach przemian instytucjonalnych, red. A. Zybertowicz, R. Sojak, Toruń 2008, s. 209.

${ }^{71}$ AIPN, 0859/159. 
sny zastępca WUSW ds. SB w Przemyślu, oraz gen. Tadeusz Szaciłł, ówczesny szef Głównego Zarządu Politycznego LWP). Załuska uzyskiwał pozytywne decyzje paszportowe (podobnie jego współpracownicy), informowano go o prowadzonych przeciwko niemu działaniach operacyjno-śledczych, wywierał też skuteczną presję na oficerów śledczych i przedstawicieli kontroli skarbowej. Ostatecznie jednak w maju 1988 r. postawiono mu zarzuty prokuratorskie. Dotyczyły one m.in. zagarnięcia mienia społecznego o wartości 1,9 mln marek RFN, wręczenia korzyści majątkowych funkcjonariuszom publicznym w wysokości 350 tys. zł oraz oszustw podatkowych na kwotę około $90 \mathrm{mln}$ zł. Obraz działań Załuski dodatkowo komplikuje fakt, że w grudniu 1986 r. przeszedł na kontakt wywiadu wojskowego ${ }^{72}$.

Spora część podobnych przykładów wskazuje na kolejny ważny obszar działania ZOF: sprawy paszportowe ${ }^{73}$. Paszport w niektórych środowiskach pozostawał dobrem rzadkim aż do stopniowej liberalizacji polityki paszportowej po stanie wojennym ${ }^{74}$. W połączeniu z woluntaryzmem w podejmowaniu decyzji w tej kwestii (na co zezwalała m.in. ogólnikowość przepisów oraz zasada niepodawania faktycznych przyczyn odmów) wytworzyło to strukturalne warunki sprzyjające korupcji wśród funkcjonariuszy SB (głównie pionu paszportowego). Hipoteza, że w latach siedemdziesiątych lub osiemdziesiątych w niemal każdym województwie miała miejsce afera paszportowa, jest więcej niż prawdopodobna ${ }^{75}$; znajduje to odzwierciedlenie w sprawach prowadzonych przez ZOF:

— gdański IOF prowadził sprawę „Video”, w której o przyjmowanie korzyści majątkowych podejrzewano sześciu funkcjonariuszy gdyńskiego Referatu Paszportów. Dwóch z nich zostało zwolnionych dyscyplinarnie, a następnie skazanych: pierwszy na dwa i pół roku oraz 700 tys. zł grzywny, drugi na rok i trzy miesiące oraz 150 tys. zł grzywny. Obaj przyjęli łapówki od ponad czterdziestu osób. W tym samym procesie zarzuty postawiono także dziewiętnastu cywilom ${ }^{76}$;

— w sprawie „Tulipan” z 1986 r. udowodniono, że w stanie wojennym ppłk Jan Baranowski, naczelnik Wydziału Kryminalnego toruńskiego WUSW, pomógł w wydaniu paszportu pewnemu obywatelowi. Dodatkowo sprawił, że za łapówkę (ok. $300 \mathrm{~g}$ złota) milicja zaniechała czynności służbowych wobec pewnego Cygana. Odstąpiono od zwolnienia dyscyplinarnego, ale ppłk Baranowski sam złożył wniosek o zwolnienie w 1987 r. $^{77}$;

— postępowanie wyjaśniające wobec mjr. Jerzego Halwy, naczelnika Wydziału Paszportów WUSW w Bydgoszczy, ujawniło całą gamę nadużyć, m.in. wykorzystywanie stanowiska dla uzyskiwania korzyści majątkowych. Jedno z nich doty-

\footnotetext{
${ }^{72}$ Ibidem, 0859/544; S. Cenckiewicz, Dtugie ramię, s. 339.

${ }^{73}$ Zob. także A. Marcinkiewicz-Kaczmarczyk, Zarzad Ochrony Funkcjonariuszy w walce z korupcja.

${ }^{74}$ W latach 1987-1988 można mówić tu niemal o rewolucji (zob. D. Stola, Kraj bez wyjścia. Migracje z Polski 1949-1989, Warszawa 2010, s. 333-336).

${ }^{75}$ Jedna z poważniejszych dotyczyła KW MO w Katowicach z lat 1980-1982, choć jej początki sięgały połowy lat siedemdziesiątych. Zaangażowani $\mathrm{w}$ nią byli nie tylko funkcjonariusze pionu paszportowego, ale też esbecy z pionów II i III (łapówki i inne korzyści w zamian za pozytywne rekomendacje paszportowe oparte na fałszywych korzyściach operacyjnych). Skutkiem tej afery było siedemnaście postępowań dyscyplinarnych, skutkujących przymusowym odejściem lub wyrzuceniem ze służby m.in. zastępcy komendanta wojewódzkiego MO ds. SB, naczelników Wydziału II i Wydziału Paszportów oraz innych funkcjonariuszy (AIPN, 1585/10832; ibidem, 1585/10833; ibidem, 1585/10834; ibidem, 1585/10835. Zob. także D. Wicenty, Patologie peerelowskiego MSW... Część 3: Paszporty).

${ }^{76}$ AIPN Gd, 0046/691, t. 1-4.

${ }^{77}$ AIPN, 0859/140.
} 
czyło wielokrotnych korzystnych decyzji paszportowych dla pewnego mieszkańca Bydgoszczy, który — jak się potem okazało - sprowadził do Polski dla mjr. Halwy samochód Renault 14 (jego wartość zresztą zaniżono dla uniknięcia naliczenia podatku dochodowego). Wyselekcjonowano sto dwanaście akt paszportowych i okazało się, że aż w dziewięćdziesięciu dziewięciu przypadkach decyzje osobiście podejmował mjr Halwa, z czego czterdzieści dziewięć spraw dotyczyła Cyganów. Spora część z nich zamieszkała na terenie województwa bydgoskiego wskutek fikcyjnych meldunków (ujawnionych w innej sprawie prowadzonej przez ZOF, w której podejrzanym był naczelnik Wydziału Kryminalnego WUSW w Bydgoszczy). Pozytywne rekomendacje dla wyjazdów Cyganów wynikały z rzekomych względów operacyjnych. Ponadto mjr Halwa utrzymywał niedozwolone kontakty z przedstawicielem firmy polonijnej „Polimar” (m.in. używał jego samochodu). W 1987 r. pozwolono mu odejść ze służby ${ }^{78}$.

Jako powody powołania ZOF gen. Kiszczak wskazał także przypadki przejścia funkcjonariuszy na stronę ,przeciwnika politycznego". Przeanalizowane przez nas dotąd sprawy nie przypominały historii kpt. Hodysza, bywały jednak przypadki mniejszej wagi:

— gdański IOF prowadził sprawę „Romeo”, zainicjowaną informacjami przekazanymi przez TW miejscowego Inspektoratu II. Por. Ryszard Olszewski (Wydział V WUSW) podejrzewany był o współpracę z działaczką podziemnej gdańskiej Solidarności, zarzucano mu też dekonspirację lokalu kontaktowego „Motława”, przyjęcie łapówek w sprawach paszportowych i wyjazdów na zagraniczne budowy oraz wyłudzenia z PZU (fikcyjne kradzieże). W sprawę łapówek i wyłudzeń zaangażowani byli także mł. chor. Andrzej Wenderlich (Wydział II WUSW; rozpracowywany przez IOF także w sprawie „Oferent”, gdzie podejrzewano zdradę) i ppor. Zbigniew Kubiak (Inspektorat II WUSW). Cała trójka została osądzona i skazana (Olszewskiemu oprócz łapownictwa i wyłudzeń udowodniono przekazywanie informacji o charakterze tajemnicy służbowej i państwowej). Ostatecznie Olszewskiemu zasądzono karę pięciu lat więzienia i $1 \mathrm{mln}$ zł grzywny, Wenderlichowi cztery lata i 400 tys. zł grzywny, a Kubiakowi trzy lata i 300 tys. zł grzywny ${ }^{79}$;

- sprawa „Niepewny” prowadzona przez chełmski IOF dotyczyła por. Zbigniewa Blacharza (Wydział IV miejscowego WUSW). W 1987 r. do chełmskiego Wydziału III zaczęły dochodzić sygnały o przeciekach płynących do miejscowych opozycjonistów. Podejrzewano, że por. Blacharz przekazuje informacje na temat pracy SB Eugeniuszowi Wilkowskiemu, działaczowi podziemnej Solidarności, a zarazem figurantowi spraw prowadzonych przez tamtejszy Wydział IV. Wilkowski okazał się dawnym kolegą por. Blacharza ze szkoły i jego znajomym. Zastosowana przez IOF prowokacja (rozpuszczenie plotki o planowanym przeszukaniu samochodu Wilkowskiego podczas uroczystości kościelnych) okazała się skuteczna. Zaobserwowano, że Wilkowski odstawił na kilka dni samochód do warsztatu, pomimo że był sprawny. „Zdradę” Blacharza potwierdzały też doniesienia miejscowej agentury; oficera zwolniono ze służby, choć uniknął sprawy karnej ${ }^{80}$.

Obserwowano także pojedyncze przypadki infiltracji resortu przez „wroga politycznego”. W sierpniu $1987 \mathrm{r}$. inspektoraty ochrony funkcjonariuszy obiegła alarmująca notatka o próbie wprowadzenia członka gdańskiej Solidarności Walczącej w szeregi ZOMO. Kandydata zi-

\footnotetext{
${ }^{78}$ Ibidem, 0859/657.

79 AIPN Gd, 0046/695, t. 1-5; AIPN, 0789/32, t. 1.

${ }^{80}$ AIPN, 0859/649.
} 
dentyfikowano jednak i odrzucono ${ }^{81}$. W SOS „Labirynt”, prowadzonej przez wrocławski IOF w latach 1984-1987, sprawdzano sprawę domniemanej dekonspiracji wobec Solidarności Walczącej wrocławskiego pionu niejawnej obserwacji. O współpracę z podziemiem podejrzewano czterech wrocławskich funkcjonariuszy (m.in. inspektorów Wydziału „B”). Sprawa prowadzona za pomocą całego zestawu środków kontroli operacyjnej (oraz przy pewnej współpracy WSW) nie potwierdziła jednak hipotezy celowej współpracy funkcjonariuszy z działaczami podziemia. Okazało się, że obok pewnego niechlujstwa w działaniu Wydziału „B” przyczyną częściowej dekonspiracji była zwykła pomysłowość w stosowaniu techniki radiowej i dobra organizacja Solidarności Walczącej ${ }^{82}$.

Odnotowywano również sporadycznie poufałe kontakty funkcjonariuszy ze środowiskami Kościoła katolickiego. Banalną na pierwszy rzut oka sprawę prowadził częstochowski IOF. Sprawdzano sygnał mówiący, że mł. chor. Jerzy Gonerski z Wydziału Ruchu Drogowego WUSW anulował mandaty karne duchownym z klasztoru na Jasnej Górze. Wkrótce się okazało, że w aktach osobowych Gonerskiego pewne nieścisłości dotyczące lat 1951-1956 mogły się wiązać z ukrytym przez niego faktem bycia alumnem bądź nawet nowicjuszem (czego ostatecznie nie zweryfikowano — dla tego okresu nie prowadzono jeszcze TEOK). Dowiedziono jednak, że Gonerski utrzymuje kontakty z oo. paulinami i postulowano jego zwolnienie ze służby. Ten ostatecznie sam odszedł, a końcowy meldunek IOF w jego sprawie wskazywał, że rzecz miała charakter ,tajemnicy poliszynela” (m.in. o powiązaniach Gonerskiego z oo. paulinami wiedział naczelnik częstochowskiego Wydziału IV) ${ }^{83}$.

Z kolei w ramach SOR „Józwa” prowadzonej przez gdański IOF sprawdzano kontakty ppor. Józefa Dębińskiego, kierownika Grupy Ruchu Drogowego w RUSW w Starogardzie Gdańskim, z kurią biskupią w Pelplinie. Podejrzewano, że świadczy on różne przysługi osobom związanym z kurią (m.in. anulowanie mandatów karnych, zwrot zatrzymanych dowodów rejestracyjnych, podmiana próbek do badania zawartości alkoholu w krwi kierowcy). Jego operatywność wynikająca z dobrych kontaktów ze starogardzką elitą (sędziowie, prokuratorzy, prawnicy, lekarze), zrazu niegroźna, spowodowała jednak poważne straty. Ppor. Dębiński zniweczył kilkumiesięczne wysiłki gdańskiego Wydziału IV, planującego zmianę biskupa pelplińskiego. W sierpniu 1988 r. funkcjonariusza wydalono ze służby ${ }^{84}$. Ogląd materiałów ZOF nie wskazuje jednak, aby środowiska kościelne stanowiły dla MSW zagrożenie porównywalne ze środowiskami firm polonijnych.

W przypadku niektórych spraw ZOF wchodził w rolę strażnika moralności. W piśmie kierownika IOF z Wrocławia z października 1985 r. czytamy: „Inspektorat Ochrony Funkcjonariuszy WUSW we Wrocławiu uzyskał potwierdzone materiały, że małżeństwo funkcjonariuszy tut. Urzędu [...] należy do grupy nudystów, a także prowadzi życie seksualne przy udziale różnych aktualnie nieznanych małżeństw. Orgie seksualne przy wymianie partnerów odbywają się w miejscu zamieszkania figurantów bądź w innych miejscowościach kraju" "85. Funkcjonariusz w środowisko intensywnego życia towarzysko-seksualnego wszedł za pośrednictwem miejscowego rzemieślnika. Ze względu na dużą częstotliwość

\footnotetext{
${ }^{81}$ AIPN Po, 078/2, t. 1 [Notatka dyrektora ZOF płk. Jacka Sosnowskiego], VIII 1987 r., k. 414.

${ }^{82}$ AIPN, 0789/206. Zob. także P. Serwadczak, Kulisy kontrwywiadu „Solidarności Walczacej”, „Biuletyn IPN” 2007, nr 5/6.

${ }_{83}$ AIPN, 0859/571, Meldunek końcowy do meldunku nr 26 z dnia 18 XII 1985, 24 VI 1981 r., k. 6.

${ }^{84}$ Ibidem, 0789/38.

${ }^{85}$ AIPN Gd, 0046/683, t. 10, pozycja 2, Pismo kierownika Inspektoratu Ochrony Funkcjonariuszy WUSW we Wrocławiu do kierownika Inspektoratu Ochrony Funkcjonariuszy WUSW w Gdańsku, 1 X 1985 r., k. 1.
} 
kontaktów z nim postanowił sprawę zalegendować, rejestrując go jako TW. Esbek nigdy nie odebrał od niego żadnej informacji; małżeństwo funkcjonariuszy zwolniono ze służby jeszcze w 1985 r. $^{86}$ Wrocławski IOF sprawdzał także sygnał o homoseksualizmie jednego z inspektorów miejscowego Wydziału III. Sygnał potwierdzono, a sytuacja stała się dla wrocławskiej SB kłopotliwa ze względu na jej widoczność (funkcjonariusz ów był wielokrotnie legitymowany nocami przez milicjantów). Przełożeni i egzekutywa POP przeprowadzali rozmowy ostrzegawczo-dyscyplinujące, co nie przyniosło pożądanych rezultatów. Ostatecznie funkcjonariusz ten odszedł ze służby na własną prośbę ${ }^{87}$. Interpretacja powyższych sytuacji powinna raczej wyjść poza perspektywę czysto etyczną ${ }^{88}$. Istotna byłaby tu pragmatyka aparatu bezpieki wyznaczana przez fundamentalną zasadę konspiracji działań. Pożycie seksualne ze współmałżonkiem czy też w ogóle heteroseksualność stanowiły pewną gwarancję „szczelności” funkcjonariusza, zwłaszcza wtedy, gdy jego życie seksualne mogłoby się stać przyczyną szantażu.

$\mathrm{Z}$ punktu widzenia konspiracji należałoby postrzegać również zagrożenia związane z innymi słabościami - choćby z hazardem czy alkoholem. Nie wchodząc w szczegółowe rozważania, trzeba tu dodać, że pijaństwo i alkoholizm w resorcie spraw wewnętrznych były rzeczywistymi problemami — od 40 do 50 proc. przewinień lub przestępstw funkcjonariusze popełniali pod wpływem alkoholu ${ }^{89}$. Aż do końca lat osiemdziesiątych kierownictwo resortu oficjalnie piętnowało te zjawiska i próbowało z nimi walczyć. Jednak nieporadność i nieskuteczność tych działań skłaniają do postawienia hipotezy, że pijaństwo/alkoholizm stały się w resorcie swego rodzaju sfunkcjonalizowaną patologią ${ }^{90}$. Nadużywanie alkoholu powodowało realne szkody, a zarazem miało charakter masowy. Walka z nim była trudna, gdyż alkohol mógł stanowić (pozorne) panaceum na napięcia emocjonalne wynikające z pracy, a ponadto był mocno zakorzeniony w stylu życia zarówno szeregowych funkcjonariuszy, jak i szefów. $Z$ tego względu walka $z$ jego nadużywaniem musiała mieć częściowo fasadowy charakter, samo nadużywanie zaś mogło stać się nieformalnym przywilejem pracowników MSW. Alkohol tolerowano, dopóki nie powodował poważnych zaniedbań w pracy.

W tym wstępnym przeglądzie spraw prowadzonych przez ZOF i obrazie resortu, jaki się tu rysuje, warto zwrócić uwagę na jeszcze jeden aspekt. Otóż można odnieść wrażenie, że Zarząd, zajmując się zarówno sprawami poważnymi, jak i błahymi, działał niezgodnie z pierwotnymi założeniami (o czym dalej). Spora część działań dotyczyła funkcjonariuszy niskich rangą lub spraw o niewielkiej szkodliwości dla resortu. Przykładowo, ZOF sprawdzał sygnał mówiący, że dwóch studentów ASW bezprawnie wykonywało czynności służbowe w Piasecznie przy sklepie z AGD, nabyło kilka sztuk telewizorów oraz manipulowało

\footnotetext{
${ }^{86}$ Zob. także AIPN, 0859/413.

${ }^{87}$ Ibidem, 0859/222.

${ }^{88}$ Przy czym „etyczność” należałoby tu rozumieć konsekwentnie w kategoriach etyki socjalistycznej. Ta zaś miała, jak się zdaje, problem z seksualnością. Z jednej strony dystansowała się od rygoryzmu w sprawach płci, z drugiej zaś sprzeciwiała się „anarchii seksualnej” i „miłości wyalienowanej” (zob. np. Z. Szawarski, Zarys moralności socjalistycznej, Warszawa 1981).

${ }^{89}$ Informują o tym m.in. roczne sprawozdania dotyczące stanu dyscypliny w aparacie spraw wewnętrznych zbierane przez GIM (zob. np. AIPN, 1585/6256; ibidem, 1585/9285; ibidem, 1585/9294; ibidem, 1585/6153).

${ }^{90}$ Odwołujemy się tu do znanego pojęcia Jadwigi Staniszkis (zob. np. eadem, Postkomunizm. Próba opisu, Gdańsk 2001).
} 
kolejką kupujących (m.in. wymuszając drobne haracze). Sygnału nie potwierdzono ${ }^{91}$. Z kolei białostocki IOF prowadził postępowanie, w którym funkcjonariusze RUSW w Sokółce byli podejrzewani o uprawę ziemi bez płacenia podatku gruntowego oraz wykorzystywanie traktorzystów mających problemy z prawem. Podejrzenia się nie potwierdziły ${ }^{92}$. Incydentalnie pojawiały się także sprawy dotyczące sportu ,gwardyjskiego" (przy resorcie funkcjonowały liczne milicyjne kluby sportowe). W jednej z nich wyjaśniano podejrzenie w stosunku do sierż. sztabowego Stanisława Pisarka (milicjanta, a zarazem pierwszego trenera bokserskiego Klubu Sportowego Gwardia Łódź), że ten w meczu bokserskim z Gwardyjskim Klubem Sportowym Walka Zabrze z 9 XII 1984 r. celowo doprowadził do przegranej własnej drużyny ${ }^{93}$. Przypomnijmy także wszystkie mało poważne ,patologie dnia codziennego" BCP ZOMO.

Z drugiej strony ZOF zajmował się realnymi i groźnymi problemami. IOF w BielskuBiałej prowadził sprawę dotyczącą fikcyjnych rozliczeń funduszu „O” w tamtejszym Wydziale III. Chodziło przede wszystkim o fałszowanie pokwitowań odbioru wynagrodzeń przez TW. Zarządzona analiza grafologiczna pokazała, że pokwitowania nie zostały podpisane przez tajnych współpracowników. Zamieszani w proceder byli ppor. Mirosław Bator i st. sierż. Stanisław Birger; pierwszy przyznał się do popełnionych przewinień i uniknął kary, drugi do końca szedł w zaparte i w końcu ukarano go ostrzeżeniem o niepełnej przydatności do służby. Co jednak najważniejsze, na fałszerstwa miał się prawdopodobnie zgadzać tamtejszy naczelnik wydziału mjr Ryszard Janik. Ten z kolei został po szczegółowej kontroli ze strony Wydziału Inspekcji zwolniony z funkcji naczelnika i oddany do dyspozycji kadr. Jednak wkrótce potem przeszedł do centrali Departamentu III, dochodząc przed rozwiązaniem SB do stanowiska zastępcy naczelnika wydziału oraz do stopnia pułkownika ${ }^{94}$. Z kolei częstochowski IOF prowadził sprawę kapitanów Zenona Liszewskiego i Jerzego Sepczyńskiego z tamtejszego Wydziału do Walki z Przestępczością Gospodarczą. Potwierdzone zarzuty dotyczyły wymuszeń haraczy od środowiska częstochowskich ,cinkciarzy”, pozorowanie pracy (np. podczas przeszukań) oraz handel zaproszeniami na Węgry i Czechosłowację. O powadze sprawy świadczy fakt, że działaniami IOF objętych było aż trzydzieści pięć osób, w tym jedenastu funkcjonariuszy, jeden były funkcjonariusz, czterech TW i dwóch byłych TW. Zarządzono też systematyczną kontrolę całej sieci agenturalnej miejscowego pionu do walki z PG, a następnie zawieszono połowę z niej. Kpt. Liszewskiego dyscyplinarnie zwolniono, kpt. Sepczyński odszedł ze służby na własną prośbę ${ }^{95}$.

\section{Skuteczność ZOF}

ZOF miał być strukturą elitarną. Przypomnijmy, że jego kadry tworzyła grupa niespełna dwustu funkcjonariuszy. Aby jednak lepiej zrozumieć znaczenie tej pojedynczej informacji, trzeba przypomnieć o zadaniach nałożonych na ZOF i wynikającej z nich skali działania. Zarząd odpowiadał za kontrolowanie funkcjonariuszy w centrali MSW i strukturach wojewódzkich, w tym SB, MO, ZOMO, jednostek pomocniczych (m.in. resortowa służba

\footnotetext{
${ }^{91}$ AIPN, 0859/1852.

92 Ibidem, 0859/1756.

${ }^{93}$ Ibidem, 0859/735, k. 89-94.

${ }^{94}$ Ibidem, 0859/406.

${ }^{95}$ AIPN Ka, 021/192, t. 20.
} 
zdrowia) oraz pracowników cywilnych. Łącznie było to około 160 tys. pracowników ${ }^{96}$. Upraszczając szacunki, daje to nam relację jednego funkcjonariusza ZOF na 1 tys. pracowników. Zarząd nie był zatem w stanie, nawet przy dużych formalnych uprawnieniach, sprawować roli superkontrolera, zdolnego do monitorowania poczynań każdego funkcjonariusza. Poza tym nie należy zapominać, że ZOF nie miał uprawnień dyscyplinarnych, śledczych bądź inspekcyjnych ${ }^{97}$. Co więcej, kierownictwo ZOF — jak wynika z wewnętrznej narady z maja 1985 r. - wcale nie chciało angażowania Zarządu w sprawy dyscyplinarne ${ }^{98}$. ZOF $\mathrm{w}$ systemie nadzoru nad funkcjonariuszami był ważnym, a może nawet kluczowym elementem, ale nie jedynym.

Trudno także wyobrazić sobie prawidłowe funkcjonowanie ZOF bez odpowiedniej współpracy między kierownikami IOF a szefami WUSW. Bez niej sytuacje, w których ZOF zdobywa informacje o nadużyciach funkcjonariusza, a ten następnie traktowany jest przez przełożonych pobłażliwie, byłyby więcej niż prawdopodobne. MSW nie było przecież jednorodną maszynerią złożoną z doskonale ze sobą współgrających elementów. Instytucja ta stanowiła także pole walk frakcyjnych i budowania sieci klientelistycznych zarówno wewnątrz, jak i na zewnątrz. Trudno powiedzieć, w jakim stopniu czynniki te zakłócały pracę ZOF, ale pojedyncze przykłady wskazują na ich istnienie. Przykładowo, opisany przypadek mjr. Halwy ujawnił konflikt między bydgoskim IOF (potem w sprawę włączyła się też centrala Zarządu) a bydgoskim Wydziałem Inspekcji. Wydział ten zaproponował karę przeniesienia na niższe stanowisko, podczas gdy IOF domagał się wyrzucenia ze służby. Kpt. Zbigniew Zemke z centrali Zarządu raportował: „Płk [Józef] Kozdra [szef WUSW w Bydgoszczy] poinformował mnie, że wpłynął do niego protokół komisji dyscyplinarnej, która proponuje ukaranie Halwy poprzez wyznaczenie na niższe stanowisko służbowe. Takie stanowisko byłoby właściwe ze względów humanitarnych. [...] Ppłk Ratajczak [naczelnik Wydziału Kadr WUSW w Bydgoszczy] sugerował, że «sprawą Halwy» interesował się I sekretarz KW PZPR w Bydgoszczy tow. Zenon Żmudziński (poseł, członek KC PZPR), a za Halwą stoją pracownicy KW PZPR w Bydgoszczy"99. Ostatecznie historia ta skończyła się dla mjr. Halwy polubownie; po orzeczeniu komisji lekarskiej (przyznana II grupa inwalidzka) Halwa w listopadzie 1987 r. odszedł ze służby.

W przedstawionym już fragmencie ukazującym typy spraw podejmowanych przez ZOF widać wyraźnie, że ich waga była bardzo różna — od gangów milicyjnych, poważnych dekonspiracji i współpracy z ,wrogiem politycznym” po drobne nadużycia. U początków swego istnienia ZOF chciał pozostawać swego rodzaju instytucją „ostatniej instancji”, angażującą siły i środki jedynie w najpoważniejszych przypadkach łamania prawa i przepisów służbowych. Świadczą o tym wyraźnie wytyczne, jakie znalazły się we wspomnianej już notatce z narady w ZOF z maja 1985 r. Zalecano tam „działać bez hałasu i reklamy”,

\footnotetext{
${ }^{96}$ Dane liczbowe osób zatrudnionych w MSW na przełomie lat 1989/1990 za: P. Piotrowski, Przemiany w MSW, s. 45.

${ }^{97}$ Niemal od początku istnienia struktur bezpieki funkcjonowała komórka odpowiedzialna za funkcje kontrolno-inspekcyjne (m.in. kontrola organizacji i dyscypliny pracy, przestrzegania tajemnicy państwowej i służbowej, kontrola jakości pracy operacyjnej i śledczej). Początkowo był to Inspektorat Ministra BP (od 1951 r.), następnie w 1955 r. Inspektorat Przewodniczącego KdsBP, a od 1956 r. aż do 1989 był to Główny Inspektorat MSW (na poziomie wojewódzkim odpowiadały mu wydziały inspekcji). 98 AIPN Po, 078/2, t. 3, Notatka służbowa z narady w Zarządzie Ochrony Funkcjonariuszy Warszawa 29-30 V 1985, 3 VI 1985 r., k. 184.

${ }^{99}$ AIPN, 0859/90, Raport [kpt. Zbigniewa Zemkego do dyrektora ZOF płk. Jacka Sosnowskiego], 30 IV 1987 r., k. 72, 74.
} 
„działać rozważnie, nie paraliżować pracy jednostek”, „kierować sprawy do prokuratury bardzo rozważnie i tylko w sprawach drastycznych” oraz ignorowanie „drobnych łapówek", którymi powinni zająć się przełożeni ${ }^{100}$. W praktyce jedynie częściowo udało się wcielić taką fillozofię działania.

Mimo stosunkowo nielicznej obsady kadrowej ZOF nie poradził sobie do końca swojego istnienia z problemem wakatów. Przykładowo, w 1989 r. czternaście etatów Zarządu pozostawało nieobsadzonych. Na jedną z realnych przyczyn tego stanu rzeczy wskazał dyrektor ZOF płk Jacek Sosnowski w piśmie do ministra Kiszczaka z grudnia 1986 r.: „Melduję Towarzyszowi Ministrowi, że pomimo prowadzonego doboru kandydatów do służby w ZOF MSW pozostało do obsadzenia 25 proc. wakatów operacyjnych. $Z$ uwagi na odmawianie przez dyrektorów jednostek resortu spraw wewnętrznych wyrażania zgody na przeniesienie do ZOF wytypowanych kandydatów, zwracam się do Towarzysza Ministra z uprzejmą prośbą o wydanie polecenia dyrektorowi Departamentu Kadr o spowodowanie przeniesienia do ZOF MSW niżej wymienionych oficerów"101. Niechęć ta do pewnego stopnia była zrozumiała ZOF zabierał doświadczonych oficerów.

Na kolejny ważny czynnik wpływający na skuteczność ZOF zwraca uwagę fragment pisma szefa WUSW w Poznaniu. W maju 1986 r. płk Zdzisław Stocki pisał: „Stwierdzono, że nie wszyscy kierownicy jednostek organizacyjnych WUSW [...] informują niezwłocznie IOF o naruszeniach prawa i powiązaniach przestępczych funkcjonariuszy i członków ich rodzin oraz pracowników cywilnych, a w niektórych przypadkach dokonują samowolnej selekcji uzyskiwanych informacji"102. Przypomnijmy, że rola ZOF w zdobywaniu informacji we wstępnej fazie była w zasadzie bierna - sygnały miały spływać od kierowników komórek resortu, jak określano to w Zarządzeniu nr 0073/84. Jeśli ci nie wywiązywali się z tego, ZOF był w znacznej mierze odcięty od informacji. Nie sposób jednak na podstawie zachowanych dokumentów stwierdzić, czy i jak poważny był to problem. W sprawozdaniu z działalności Zarządu za rok 1985 czytamy: „Z uwagi na znikomy dopływ informacji od niektórych kierowników jednostek resortu spraw wewnętrznych o naruszeniach prawa przez funkcjonariuszy zintensyfikować współdziałanie i kontakty z przełożonymi różnych szczebli w celu zwiększenia dopływu informacji z zakresu zainteresowań pionu ZOF"103. W sprawozdaniach za kolejne lata wątków takich już nie znajdujemy. Brakuje także wyraźnych oznak obstrukcji Zarządu. Poza tym ZOF dysponował też alternatywnymi kanałami informacji. Przykładowo, dotychczasowa analiza kilkuset różnego rodzaju spraw i postępowań wyjaśniających wskazuje, że kanałem takim były anonimy słane do szefów WUSW, MSW, prokuratury lub komitetów wojewódzkich $\mathrm{PZPR}^{104}$. Hipoteza obstrukcji ZOF wydaje się jednak ważnym tropem $\mathrm{w}$ odniesieniu do wywiadu PRL, struktury ewidentnie hermetycznej w łonie MSW. Dlaczego wśród olbrzymiej liczby spraw analizowanych przez Zarząd niemal w ogóle nie przytrafiały się do-

\footnotetext{
100 AIPN Po, 078/2, t. 3, Notatka służbowa z narady w Zarządzie Ochrony Funkcjonariuszy Warszawa 29-30 V 1985, 3 VI 1985 r., k. 183, 184, 186.

${ }^{101}$ AIPN, 0604/1865, t. 1, Pismo dyrektora ZOF płk. Jacka Sosnowskiego do ministra spraw wewnętrznych gen. Czesława Kiszczaka, 20 XII 1986 r., k. 119.

${ }_{102}$ AIPN Po, 06/274 t. 5 [Pismo szefa WUSW w Poznaniu], 2 V 1986 r., k. 5.

${ }^{103}$ AIPN, 0789/1, t. 1, Sprawozdanie z działalności Zarządu Ochrony Funkcjonariuszy MSW i jego odpowiedników w terenie za okres od 1 I do 31 XII 1985 r., 9 I 1986 r., k. 199.

${ }^{104}$ Bardzo wstępne szacunki wskazywałyby na to, że mniej więcej kilka procent postępowań mogło być inicjowanych przez donosy. Warto przy tym wskazać, że w niektórych przypadkach donos stawał się narzędziem zemsty na funkcjonariuszu.
} 
tyczące Departamentu ${ }^{105}$ ? A o tym, że pion wywiadu PRL nie był wolny od patologii, świadczy chociażby afera „Żelazo"106.

Przy ocenie ZOF trzeba wziąć pod uwagę jeszcze jeden aspekt: konspirację wewnątrz $\mathrm{MSW}^{107}$. Pojedyncze przypadki wskazują, że w praktyce konspirowanie działań nie zawsze było skuteczne. Przykładowo, funkcjonariusze objęci postępowaniem wyjaśniającym zbyt wcześnie — z punktu widzenia pragmatyki ZOF — dowiadywali się nieformalnymi kanałami o fakcie toczącego się postępowania. Poza tym niejawność działań ZOF mogła wywoływać czasem dość nieoczekiwane skutki, choćby krążące plotki. Świadomość istnienia Zarządu była zarówno dyscyplinująca, jak i pobudzająca wyobraźnię. ZOF mógł się więc jawić się w dość zniekształconej, a może wręcz zdemonizowanej postaci. Kierownictwo Zarządu było przynajmniej częściowo świadome specyficznego jego wizerunku. W notatce $\mathrm{z}$ grudnia 1989 r. czytamy: „Prawdopodobnie błędem kierownictwa ZOF MSW jest brak nacisków na kierownictwa służbowe jednostek resortu o doprowadzenie do kolektywów pracowniczych wiedzy na temat faktycznej roli oraz skuteczności działań pionu ochrony funkcjonariuszy. [...] Zdumiewającym było przekonanie szefów RUSW, że pion ochrony funkcjonariuszy organizuje i prowadzi w ich jednostkach systematyczne i wynikające z zadań statutowych rozpoznanie operacyjne, a także pozyskuje podległych im funkcjonariuszy w charakterze tajnych współpracowników"108. Dodajmy - oczywiście ZOF takich uprawnień nie miał.

Na koniec powiedzmy, że odrębnej analizy funkcjonowania Zarządu wymagałby także okres po wyborach czerwcowych z 1989 r. ZOF został oficjalnie rozwiązany 15 II 1990 r., a proces likwidacji trwał do marca tegoż roku. Kiedy miało miejsce wyhamowanie pracy ZOF? Przypomnijmy, że w całym roku 1989 obserwowaliśmy wyraźnie niższą liczbę spraw w odniesieniu do lat poprzednich (zob. tabela nr 2). Jak wpłynął na to zmieniający się kontekst polityczno-ustrojowy? Czy jakieś znaczenie dla funkcjonowania ZOF w końcowych miesiącach miały inicjatywy założycielskie NSZZ „Solidarność” w strukturach MSW? Rzecz wymaga zbadania. Pojedyncze przypadki wskazują, że nowo powstałe struktury związkowe

${ }^{105} \mathrm{~W}$ zasadzie tylko w dwóch przypadkach natknęliśmy się na sprawy dotyczące oficerów wywiadu PRL. Tłem sprawy dotyczącej ppłk Zofii Krzysztoszek, wykładowcy Akademii Spraw Wewnętrznych, był jej syn Janusz Krzysztoszek, oficer Departamentu I, który został zwolniony dyscyplinarnie w maju 1985 r. (chodziło o m.in. ujawnienie osobie nieuprawnionej wiadomości służbowej oraz prywatne spotkania z figurantami spraw Departamentu I bez wiedzy i zgody kierownictwa. Ponadto w styczniu 1985 r. Janusz Krzysztoszek zawarł związek małżeński z Polką na stałe mieszkającą w USA). Planowano w związku z tym zwolnić Zofię Krzysztoszek, która ostatecznie sama odeszła z resortu w 1986 r. (AIPN, 0859/395). Przypadek drugi został skrótowo opisany w sprawozdaniu ZOF za $1986 \mathrm{r}$. Chodziło tam o ppłk. Zbigniewa Zielińskiego, st. inspektora Departamentu I, który wykorzystywał stanowisko służbowe do zorganizowania przemytu i handlu dziełami sztuki (ibidem, 0789/1, t. 1, Sprawozdanie z działalności Zarządu Ochrony Funkcjonariuszy MSW i jego odpowiedników w terenie za okres od 1 I-31 XII 1986 roku, 9 I 1987 r., k. 167).

106 Zob. Afera ,Żelazo” w dokumentach MSW.

${ }^{107}$ Kwestia faktycznego funkcjonowania zasady konspiracji wymaga odrębnej analizy, dotyczącej także relacji z otoczeniem MSW. Przykładowo, intrygująca wydaje się sprawa związana z wyciekiem informacji o powstaniu ZOF do środowisk podziemnej Solidarności w Szczecinie. Miejscowy IOF badał okoliczności publikacji w miesięczniku „Obraz” z lutego 1985 r., przedrukowanego potem w czasopiśmie „KAT. Krajowa Agencja Terenowa”. Artykuły te informowały o powstaniu w strukturach WUSW „wydziału do inwigilowania funkcjonariuszy MO i SB oraz ich rodzin”. Podejrzewano, że nie był to przypadkowy wyciek informacji, ale nie ustalono żadnych sprawców (AIPN, 0859/107).

${ }^{108}$ Ibidem, 0789/1, t. 2, Notatka, 13 XII 1989 r., k. 25. 
wystawiały funkcjonariuszom IOF w poszczególnych województwach swego rodzaju świadectwa ,prawości”109.

\section{Zakończenie — nowe pola do badań nad aparatem represji w PRL}

Dokumenty pozostałe po ZOF otwierają niewątpliwie nowe obszary analiz dotyczących aparatu bezpieki. Dość oczywisty trop wiódłby m.in. do studiów na temat wewnętrznych mechanizmów dyscyplinowania i kontroli nad funkcjonariuszami bezpieki ${ }^{110}$. Jedno $\mathrm{z}$ innych nowych pól to refleksja nad problemem różnego rodzaju patologii w łonie SB (i szerzej całego MSW). Inspiracją dla tej ścieżki analizy mogą być tu pionierskie prace polskiego socjologa Adama Podgóreckiego, który zwrócił uwagę na patologie organizacyjne, a więc te elementy struktur organizacyjnych, wewnętrznych stosunków społecznych oraz relacji z otoczeniem zewnętrznym, które skutkują niemożnością osiągania przez organizację jej podstawowych celów lub nawet ich konwersją. W wypadku tego ostatniego można się zasadnie zastanowić, jakie stwierdzone elementy patologii w łonie bezpieki wywoływały właśnie skutki o charakterze strukturalnym - a więc, przykładowo, częściową przynajmniej niezdolność do odgrywania roli tajnej policji politycznej lub też konwersję sił i środków SB na przedsięwzięcia prywatne lub/i przestępcze ${ }^{111}$.

Inny możliwy trop analiz wyznacza Gary T. Marx, amerykański socjolog i badacz służb specjalnych. W swoim tekście poświęconym mechanizmom i instytucjom wewnętrznej kontroli w amerykańskiej policji i FBI zwraca uwagę m.in. na systemowy charakter niektórych patologii (np. korupcji funkcjonariuszy). Tym samym za częściowo nietrafne uznaje podejście do problemu patologii z perspektywy pojedynczego funkcjonariusza (metafora ,zgniłego jabłka” lub „czarnej owcy”). Marx wskazuje także na strukturalne czynniki kształtujące systemy wewnętrznej kontroli, w tym system kar i nagród, obszar sposobności łamania reguł działania, społeczną ,widzialność” nadużyć, stopień profesjonalizacji oraz typ organiza$\mathrm{cji}^{112}$. Tu od razu dodajmy, że w aparacie MSW refleksja nad systemowymi uwarunkowaniami nadużyć w zasadzie zupełnie nie występowała. Obowiązywała w zasadzie jednostkowa perspektywa: za nadużycia odpowiadały „czarne owce” lub „zgniłe jabłka”, które trzeba zidentyfikować i wyrzucić ${ }^{113}$. W tym kontekście cenne byłoby zrekonstruowanie i przeanalizowanie wszystkich formalnych i nieformalnych mechanizmów kontroli i dyscyplinowania funkcjonariuszy, począwszy od struktur (np. GIM i ZOF), przez regulaminy i normatywy, a skończywszy na obyczajowości, stylach życia funkcjonariuszy i codziennych relacjach przełożony-podwładny.

\footnotetext{
${ }^{109}$ Przykładowo, kierownik poznańskiego IOF w notatce z 12 II 1990 r. raportował szefowi ZOF: „Uprzejmie informuję, że Komitet Założycielski NSZZ F[unkcjonariuszy] MO Województwa Poznańskiego opublikował w jednostkach tut. garnizonu komunikat jednoznacznie stwierdzający, że IOF w Poznaniu nie podejmował działań na szkodę funkcjonariuszy MO” (AIPN Po, 078/2, t. 1, Pismo Kierownika IOF w Poznaniu do Dyrektor ZOF, 12 II 1990 r., k. 720).

${ }_{110}$ Zob. np. A. Zieliński, Materiaty kontroli resortowych jako przedmiot badań historyka, „Przegląd Archiwalny Instytutu Pamięci Narodowej” 2013, t. VI.

${ }^{111}$ Szerzej - zob. D. Wicenty, Patologie w Stużbie Bezpieczeństwa. Szkic projektu badawczego, „Prace IPSiR UW" 2012, t. XX.

${ }^{112}$ G. T. Marx, When the guards guard themselves: undercover tactics turned inward, „Policing and society" 1992, t. II, nr 3.

${ }^{113}$ Być może jest to bardziej uniwersalna skłonność poznawcza, obecna także w policjach funkcjonujących w systemach demokratycznych (zob. np. A. J. Reiss Jr., Police Organization in the Twentieth Century, „Crime and Justice” 1992, t. XV).
} 
Marx skłonny byłby w strukturach „policji w policji” widzieć rozwiązanie dylematu wyrażonego maksymą Quis custodiet ipsos custodes?, przypisywaną rzymskiemu poecie Juwenalisowi z Akwinu ${ }^{114}$. Z tego punktu widzenia ZOF niwelowałby potencjalny deficyt kontroli nad bezpieką. Z kolei dla Hanny Arendt struktura kontrolna nad jądrem systemu władzy — tajną policją polityczną — to emanacja filozofii systemu totalitarnego, zakładającej istnienie wzajemnie nakładającej się i nieprzejrzystej siatki kontrolnej, z elementami metakonspiracji oraz wyróżnioną rolą ,policji w policji”"15. Skrupulatna analiza funkcjonowania ZOF powinna zatem spróbować odpowiedzieć na pytanie, czy była to struktura powołana w sytuacji racjonalnych obaw o stan dyscypliny funkcjonariuszy, czy też stanowiła kolejne narzędzie kontroli nad aparatem bezpieczeństwa, stopniowo przejmowanego przez gen. Kiszczaka i jego wojskowych od początku lat osiemdziesiątych.

Słowa kluczowe: Zarząd Ochrony Funkcjonariuszy MSW, dyscyplina i nadużycia w MSW w drugiej połowie lat osiemdziesiątych, kontrola społeczna, dylemat Quis custodiet ipsos custodes?

\section{Bibliografia}

Afera ,Żelazo” w dokumentach MSW i PZPR, wybór, wstęp i oprac. W. Bagieński, P. Gontarczyk, Warszawa 2013.

Arendt H., Korzenie totalitaryzmu, t. I, tłum. D. Grinberg, M. Szawiel, Warszawa 1993.

Cenckiewicz S., Dtugie ramię Moskwy. Wywiad wojskowy Polski Ludowej 1943-1991 (wprowadzenie do syntezy), Poznań 2011.

Cenckiewicz S., Operacja ,Arka”, czyli SB w walce z Ruchem Młodej Polski, [w:] idem, Oczami bezpieki. Szkice i materiały z dziejów aparatu bezpieczeństwa PRL, Kraków 2006, wyd. 3.

Dominiczak H., Organy bezpieczeństwa PRL 1944-1990. Rozwój $i$ działalność $w$ świetle dokumentów MSW, Warszawa 1997.

Dull M., Roberts P. S., Guarding the guardians: oversight appointees and the search for accountability in U.S. federal agencies, „The Journal of Policy History” 2013, t. XXV, nr 2.

Gontarczyk P., Raport z działalności Komisji powołanej do wyjaśnienia charakteru operacji kryptonim , ¿̇ELAZO”, „Glaukopis” 2006, nr 7/8.

Gontarczyk P., Cenckiewicz S., SB a Lech Watęsa. Przyczynek do biografii, Gdańsk-WarszawaKraków 2008.

Kordas J., Piłsudczycy w Komendzie Wojewódzkiej Milicji Obywatelskiej we Wrocławiu — „, Grupa Charukiewicza”, w: Czas przełomu: Solidarność 1980-1981, red. W. Polak i in., Gdańsk 2010.

Marcinkiewicz-Kaczmarczyk A., Zarzad Ochrony Funkcjonariuszy w walce z korupcja $w$ latach 1984-1990, w: Społeczno-prawne aspekty przeciwdziałania korupcji, red. J. Bil, A. Wawrzusiszyn, Szczytno 2012.

Marx G. T., When the guards guard themselves: undercover tactics turned inward, „Policing and Society" 1992, t. II, $\mathrm{nr} 3$.

Morale funkcjonariuszy SB $i$ MO w Matopolsce w ostatnich latach PRL (wybór dokumentów), oprac. P. Milczanowski, ,Zeszyty Historyczne WiN-u” 2010, nr 32-33.

Paczkowski A., Dowódca czy przywódca? Wojciech Jaruzelski 1981-1989, w: Władza w PRL. Ludzie i mechanizmy, red. K. Rokicki, R. Spałek, Warszawa 2011.

\footnotetext{
114 Por. także P. S. Roberts, M. Dull, Guarding the guardians: oversight appointees and the search for accountability in U.S. federal agencies, „The Journal of Policy History” 2013, t. XXV, nr 2.

${ }^{115}$ H. Arendt, Korzenie totalitaryzmu, t. I, thum. D. Grinberg, M. Szawiel, Warszawa 1993, s. 440.
} 
Paczkowski A., PZPR a aparat bezpieczeństwa. Zarys problemu, w: PZPR jako machina władzy, red. D. Stola, K. Persak, Warszawa 2012.

Piotrowski P., Obsada kierowniczych stanowisk $w$ aparacie bezpieczeństwa $w$ latach 1975-1990, w: Aparat bezpieczeństwa w Polsce. Kadra kierownicza, t. III: 1975-1990, red. idem, Warszawa 2008.

Piotrowski P., Przemiany w MSW w latach 1989-1990, „Biuletyn IPN”2004, nr 4.

Piotrowski P., Stużba Bezpieczeństwa w latach 1975-1990, w: Aparat bezpieczeństwa w Polsce. Kadra kierownicza, t. III: 1975-1990, red. idem, Warszawa 2008.

Reiss Jr. A. J., Police Organization in the Twentieth Century, „Crime and Justice” 1992, t. XV.

Serwadczak P., Kulisy kontrwywiadu ,, Solidarności Walczacej”, „Biuletyn IPN” 2007, nr 5/6.

Stola D., Kraj bez wyjścia. Migracje z Polski 1949-1989, Warszawa 2010.

Sumliński W., Teresa, Trawa, Robot. Największa operacja komunistycznych stużb specjalnych, Warszawa 2009.

Szawarski Z., Zarys moralności socjalistycznej, Warszawa 1981.

Szporer M., Solidarity. The Great Workers Strike of 1980, Lanham 2012.

Szwagrzyk K., Aparat bezpieczeństwa w latach 1944-1956, w: Aparat bezpieczeństwa w Polsce. Kadra kierownicza, t. I: 1944-1956, red. idem, Warszawa 2005.

Wicenty D., Patologie w Stużbie Bezpieczeństwa. Szkic projektu badawczego, „Prace IPSiR UW” 2012, t. 20.

Zieliński A., Materiaty kontroli resortowych jako przedmiot badań historyka, „Przegląd Archiwalny Instytutu Pamięci Narodowej” 2013, t. VI.

Zybertowicz A., Przemoc „układu” — na przykładzie sieci biznesowej Zygmunta Solorza, w: Transformacja podszyta przemoca. O nieformalnych mechanizmach przemian instytucjonalnych, red. A. Zybertowicz, R. Sojak, Toruń 2008.

\section{Kiszczak's "Police within the Police". On the Department for the Protection of Functionaries (1985-1990)}

The article is about the Department for the Protection of Functionaries (Zarzad Ochrony Funkcjonariuszy - ZOF), a heretofore insufficiently examined structure, which in 19851990 fulfilled the function of a "police within the police" in the Ministry of Internal Affairs. The author discussed the circumstances of the origin of ZOF, including changes inaugurated after the appearance at the Ministry of General Czesław Kiszczak (i.a. the Ministry's militarisation), the arrest and trial of Captain Adam Hodysz, and the death of Rev. Jerzy Popiełuszko. The text provides a synthesis of the functioning of ZOF within the context of its tasks, rights, structures, and staff, with the author describing typical and unusual cases of abuse discovered by ZOF, such as corruption in the passport department, the "treason" committed by the functionaries for the sake of the "political opponent", and the on-the-spot or organised use made of Militia and Security Service structures and means for private purposes (including the activity of sui generis Militia gangs and symbiotic relations between the functionaries and the private sector). The article also takes into account the effectiveness of ZOF and ends by outlining new fields of research offering, i.a. sociological analyses of pathologies and social control mechanisms in the Ministry of Internal Affairs. 